\title{
Application of physiographic soil erosion-deposition model in estimating sediment flushing efficiency of empty storage
}

\author{
Ching-Nuo Cheno \\ International Master Program in Soil and Water Engineering, National Pingtung University of Science and \\ Technology, Pingtung 912, Taiwan. \\ e-mail: ginrochen@mail.npust.edu.tw
}

MS received 21 February 2017; revised 22 January 2018; accepted 23 January 2018; published online 2 August 2018

In this study, we developed a physiographic soil erosion-deposition model to simulate sediment yield from a watershed into Agongdian reservoir and sediment flushing to estimate the efficiency of empty flushing. The model was verified using data related to Typhoons Morakot and Fanapi. Thereafter, we calculated the sediment flushing efficiency of empty storage under the conditions of 1- and 2-day storms with seven return periods. The simulated results revealed that the amount of sediment yield from Joushui River watershed was approximately $70 \%$ on average, whereas that from Wanglai River watershed was approximately 30\%. These results are consistent with those of a government research report, which suggested that the sediment yield figures from Joushui and Wanglai River watersheds were 72 and $28 \%$, respectively. Furthermore, the efficiency of empty flushing was more than $55 \%$ when using the shaft spillway pipe, suggesting that the model can be applied to estimate sediment yield and flushing efficiency.

Keywords. Shaft spillway pipe; physiographic soil erosion-deposition model; runoff; sediment yield; efficiency of empty flushing.

\section{Introduction}

A reservoir can be used for storage to effectively convert flood water into a water resource available for use, thereby facilitating drought relief efforts. Flood control requires the maximum possible empty space, whereas water storage is required for the water supply, irrigation, recreation, and hydropower. The effective volume of a reservoir gradually decreases because of the amount of sediment deposited from upstream watershed movement, thereby affecting the reservoir's functions (Chaudhry et al. 2014). According to Chang et al. (2003), to sustain the long-term usefulness of a reservoir, reservoir desiltation is a crucial technique because of the lack of suitable dam sites, high cost of dam construction, and strict environmental regulations. Maintaining existing reservoir storage functions is a notable concern, as evidenced by the large number of reservoir sedimentation management topics discussed by various researchers worldwide (Kondolf et al. 2014). Several techniques have been applied to address the problems of sedimentation. Mueller et al. (2010) applied the WASA-SED model to simulate the runoff, erosion, and transport and retention processes of suspended and bedload fluxes in river reaches as well as the retention and remobilization processes of sediment in reservoirs. Castillo et al. (2015) analyzed the complex phenomenon of sedimentation and 
flushing by using four interrelated methodologies: empirical formulations and one-, two-, and threedimensional (3D) simulations.

Because of Taiwan's peculiar topography and geological conditions such as steep terrain, short rivers, and high flow velocities, water is difficult to store. Moreover, the temporal and spatial distributions of precipitation are extremely non-uniform. Precipitation is concentrated in the wet season, which accounts for $78 \%$ of the annual precipitation (Chen et al. 2007). This exacerbates the difficulty of apportioning water around the island. Therefore, reservoirs are imperative for storing rain water during the wet season for use in the dry season. However, the combination of fragile sandstone and poor geological characteristics in Taiwan watersheds render the watersheds more vulnerable to landslides and erosion. Consequently, heavy buildup of sediment is deposited into reservoirs. The results of a survey conducted by the Water Resources Agency (2013) on the four main dams in Taiwan indicated that sedimentation in these dams was higher than $30 \%$. Therefore, reservoir siltation is a common problem in Taiwanese reservoirs. To mitigate the problem of siltation, dredging is usually conducted at an applicable time to increase the effective storage capacity of reservoirs and extend their life span, thereby ensuring sustainable management and utilization.

To study the efficiency of reservoir flushing, knowledge of the sediment volumes and their sources and controlling parameters is indispensable (Tena et al. 2014). Several approaches are available for estimating sediment yield in reservoirs. These approaches can be grouped into field measurement, empirical models, physically-based soil erosion-deposition models, and numerical models. Field measurement for estimating sediment yield is fundamentally based on the relationship between the suspended sediment transport rate and flow discharge; this relationship can be established from suspended sediment and discharge data recorded at a hydrological station (Vanoni 1975). Empirical models have been developed from statistical analyses of information obtained from experiments or field measurements such as the Universal Soil Loss Equation USLE (Wischmeier and Smith 1978), Modified USLE (Williams 1975), and Revised USLE (Renard et al. 1991). Although these models are easy to use, they describe only the erosion processes for overland flow. Among other limitations, they are only applicable to the areas from which they are derived (or similar areas).
Physics-based models are considered to be pure mathematical models used to simulate soil erosion processes based on the conservation of energy and mass principles, and the examples include ANSWERS (Beasley et al. 1980), WEPP (Nearing et al. 1989; Brazier et al. 2000), and EUROSEM (Morgan et al. 1998). These models can simulate the process of soil erosion and deposition under steady conditions, but cannot simulate dynamic processes such as rainfall runoff. Applications of the ANSWERS model in studies by Estakhri (1999) and Singh et al. (2006) have revealed that the model prediction of sediment concentration is not particularly close to the observed values.

In recent years, several numerical models considering rainfall runoff and sediment transport to simulate soil erosion or sediment yield have been developed. Ziegler et al. (2001) successfully applied the KINEOS2 model to simulate field and road rainfall in northern Thailand. However, dynamic distributed flow modeling has two major limitations; it is suitable only where runoff generation is dominated by Horton overland flow with minimal contributions from return flow, and also where sediment transport varies throughout the course of a storm. A spatially distributed rainfall runoff-soil erosion model (Sun et al. 2002) capable of handling catchment heterogeneity in terms of land use, soil, slope, and rainfall was developed and applied to data from several catchments. The application of this model in several catchments indicated that the model can compute temporal distribution of the sediment outflow rate at the catchment outlet for storm events to a reasonable degree of success. Furthermore, the cell-based structure of the model enables computation of the spatial distribution of computed variables such as the degree of soil erosion. However, each (regular) cell of the discretised catchment has only eight possible flow directions, and this could be a limitation in a natural environment. In our physiographic soil erosion-deposition (PSED) model, the cells are irregular to enable full resemblance to complex natural phenomenon. Moreover, the hydrological and physiographical factors in watersheds are not only complex but also vary in the natural environment. Therefore, if a model cannot reflect changes in hydrological and physiographical factors instantaneously within the watersheds, its application and simulation accuracy are limited.

To effectively manage the large number of geographic and hydrological parameters in a watershed and consider the dynamics of the soil erosion 
process, we combined a geographic information system (GIS) with a rainfall-runoff model, sediment transport model, and slope soil erosion model to develop the PSED model for computing the runoff and sediment yield. The model considers various factors, including the impact of erosion, entrainment, and deposition of sediment on a riverbed. Because the model utilizes a GIS, hydrological and physiographical factors can be processed instantaneously. Any changes in these factors are incorporated in a timely manner. A runoff hydrograph and suspended sediment concentration hydrograph and data on sediment yield and changes in soil erosion and deposition can all be obtained from the PSED model. The model was successfully used in a study by Wu et al. (2012) on the Tsengwen reservoir watershed, where the simulated sediment concentration in the reservoir and subsequent deposition were in close agreement with the observed measurements. Chen et al. (2011) simulated runoff and suspended sediment transport in a basin with multiple watersheds. In the present study, we combined the PSED model with the sediment flushing of the empty storage operation rule to simulate the flow hydrograph entering a reservoir, the sediment hydrograph, suspended sediment transport rate hydrograph, sediment yield from a watershed into the reservoir, and sediment flushing of the shaft spillway pipe for the reservoir.

\section{Physiographic soil erosion-deposition model}

To construct the physiographic soil erosiondeposition model in this study, GIS was used to partition the river watershed into computed cells according to the spatial distribution of the physiography. The cells were classified as either land cells or river cells. The physiographic and hydrological data of each cell were obtained through GIS analysis. Generally, computations in PSED model may be divided into two parts further detailed below.

\subsection{Water flow calculations}

The purpose of water flow calculation is to calculate runoff in the watershed. Calculations are based on continuity equation and discharge formulas with the continuity equation by (Yang 2000)

$$
A_{s i} \frac{\partial h_{i}}{\partial t}=\sum_{k} Q_{i, k}\left(h_{i}, h_{k}\right)+P_{e i}(t)
$$

where $t$ is time; $A_{s i}$ is the area of the $i$ th cell; $h_{i}$ is the water depth in the $i$ th cell; $h_{k}$ is the water stage in the $k$ th cell; $Q_{i, k}$ is the discharge from the $k$ th cell into its neighbouring $i$ th cell; $P_{e i}$ is the effective rainfall volume in the $i$ th cell, which is equal to the effective rainfall intensity multiplied by the area of the cell.

The effective rainfall volume can be obtained using equations (2 and 3) (Chow et al. 1988)

$$
\begin{aligned}
P^{\prime} & =\frac{(P-0.2 S)^{2}}{(P+0.8 S)} \\
S & =\frac{25400}{C N}-254
\end{aligned}
$$

where $P$ is the depth of total precipitation $(\mathrm{mm})$; $P^{\prime}$ is the depth of excess precipitation or direct runoff (mm); $S$ is less than or equal to the potential maximum retention $(\mathrm{mm}) ; C N$ is curve number.

However, if no obvious obstacles exist between neighbouring cells where flow took place, then the Manning formula may be used to calculate the flow from a cell to its neighbouring cell. Accordingly, the flow of water from the $k$ th cell into its neighbouring $i$ th cell can be denoted as follows

$$
\begin{aligned}
Q_{i, k}= & \frac{h_{k}-h_{i}}{\left|h_{k}-h_{i}\right|} \cdot \Phi\left(\bar{h}_{i, k}\right) \cdot \sqrt{\left|h_{k}-h_{i}\right|} \\
& \text { for } \quad \frac{\partial Q_{i, k}}{\partial h_{i}} \leq 0 \\
Q_{i, k}= & \Phi\left(h_{k}\right) \cdot \sqrt{\left|h_{k}-h_{i}\right|} \text { for } \frac{\partial Q_{i, k}}{\partial h_{i}}>0
\end{aligned}
$$

where $\bar{h}_{i, k}$ is the water stage at the border of the $i$ th and $k$ th cells.

Let $\Phi(h)$ denote the flow parameter. Then it can be expressed by equation (6)

$$
\Phi(h)=\frac{(1 / n) A R^{2 / 3}}{\sqrt{\Delta x}}
$$

where $\Delta x$ is the distance between the centres of the $i$ th and $k$ th cells; $n$ is Manning's roughness coefficient for the area covered by the cells $i$ and $k$; $A$ is the cross sectional flow area between the $i$ th and the $k$ th cells; $R$ is hydraulic radius between the $i$ th and the $k$ th cells.

If the areas were divided by hydraulic structures such as embankment, field ridge, or bank, then the border may be treated as broad crested weir and the weir flow formula can be used to obtain the flow from one cell to its neighbouring cell. If $h_{k}>h_{i}$, then there are two possible cases 
(A) Free overfall weir $\left(h_{i}-h_{w}\right)<\frac{2}{3}\left(h_{k}-h_{w}\right)$ :

$$
Q_{i, k}=\mu_{f} b \sqrt{2 g}\left(h_{k}-h_{w}\right)^{3 / 2}
$$

(B) Submerged weir $\left(h_{i}-h_{w}\right) \geq \frac{2}{3}\left(h_{k}-h_{w}\right)$ :

$$
Q_{i, k}=\mu_{s} b \sqrt{2 g}\left(h_{i}-h_{w}\right)\left(h_{k}-h_{i}\right)^{1 / 2}
$$

where $h_{w}$ is the elevation of the weir crest; i.e., the elevation of the bordering road, weir crest, or ground; $b$ is the effective width of the weir, or the length of the border between two neighbouring cells; $g$ is gravitational acceleration; $\mu_{f}$ is the weir discharge coefficient in case (A) of free overfall weir; and $\mu_{s}$ is the weir discharge coefficient in case (B) of submerged weir. According to Tsai and Tsai (1997), $\mu_{f}=0.36 \sim 0.57$ and $\mu_{s}=2.6 \mu_{f}$. $\mu_{f}=0.47$ and $\mu_{s}=1.22$ were chosen in this study.

\subsection{Soil erosion calculations}

Using the suspended sediment continuity equation, bed variation continuity equation, and bed load transport rate formula, sediment transport rate and bed load sediment variation can be determined. For any cell $i$, suspended sediment continuity equations and bed variation can be written as (Chen et al. 2006)

$$
\frac{\partial V_{s i}}{\partial t}=\sum_{k} Q_{S C_{i, k}}+Q_{s e i}-Q_{s d i}+R_{D T i}
$$

where $V_{s i}$ is the volume of suspended sediment in the $i$ th cell $\left(=A_{i} \times D_{i} \times C_{i}\right.$; where $C$ is the volumetric concentration of suspended sediment); $Q_{S C_{i, k}}$ is the transport rate of suspended sediment from the neighbouring $k$ th cell into the $i$ th cell; $R_{D T i}$ is the rainfall detachment rate of the $i$ th cell; $Q_{\text {sei }}$ is the entrained sediment volume of bed in the $i$ th cell; $Q_{s d i}$ is the deposited sediment volume of bed in the $i$ th cell.

\subsubsection{Rainfall detachment rate}

In addition to soil type and vegetation, the effect of rainfall detachment is affected by flow depth. However, when flow depth exceeds three times the raindrop diameter, raindrops cease to have any impact on soil surface and rainfall detachment rate may be considered null (Mutchler and Young 1975). Raindrop diameter often correlates with rainfall intensity. In this study, Ma (1995) formula is used to estimate the raindrop diameter

$$
d_{50}=1.560 I^{0.096}
$$

where $d_{50}$ is the median value of raindrop diameter in $\mathrm{mm}$; $I$ is rainfall intensity in $\mathrm{mm} / \mathrm{hr}$.

When flow depth is less than three times the raindrop diameter, the rainfall detachment rate in the cell may be expressed as:

$$
R_{D T i}=a \cdot I^{b} \cdot c^{\prime} \cdot A_{i}
$$

where $a$ and $b$ are variables yet to be determined. Sharma et al. (1995) suggested that $b$ be less than 1. Hu et al. (1995) found that the range of $a$ was between 18.36 and 21.72 , and that of $b$ was between 0.81 and 1.29. In this study, $a=20.04$ and $b=1.05$ were selected as we averaged the respective ranges.

\subsubsection{Entrained sediment and deposition sediment}

According to Itakura and Kishi (1980), the entrained sediment volume per unit width of channel bed can be expressed as:

$$
q_{s e}=0.008 \sqrt{s g d}\left[0.14 \frac{\rho}{\rho_{s}}\left(14 \sqrt{\tau_{*}}-\frac{0.9}{\sqrt{\tau_{*}}}\right)-\frac{\omega_{s}}{\sqrt{s g d}}\right]
$$

in which $s=\left(\rho_{s}-\rho\right) / \rho$ is the submerged specific gravity of the sediment; $\rho_{s}$ is sediment density; $\rho$ is water density; $d$ is sediment diameter; $\omega_{s}$ is sediment fall velocity; $\tau_{*}$ is non-dimensional bed shear stress and can be expressed as $\tau_{*}=u_{*}^{2} / s g d ; u_{*}$ is the shear velocity.

The deposition rate of suspended sediment, $q_{s d}$, can be expressed as:

$$
q_{s d}=\omega_{s} C .
$$

Thus, the volumes of entrained sediment and the deposited sediment per unit width of channel bed in the $i$ th cell can be expressed as

$$
\begin{gathered}
Q_{s e i}=q_{s e} \cdot A_{i} \cdot c^{\prime} \quad(\text { if cell } i \text { is a land cell }) \\
Q_{\text {sei }}=q_{s e} \cdot A_{i} \quad(\text { if cell } i \text { is a river cell }) \\
Q_{s d i}=q_{s d} \cdot A_{i}
\end{gathered}
$$

where $c^{\prime}$ is the coverage factor which is related to land use type. 


\subsubsection{Sediment fall velocity}

The terminal fall velocity that a particle attains in a quiescent of water, $\omega_{0}$ is derived as follows:

$$
\omega_{o}=\frac{1}{18} \frac{\gamma_{s}-\gamma}{\gamma} \frac{g d^{2}}{\nu}
$$

where $\gamma_{s}$ and $\gamma$ are the specific weight of sediment and water, respectively; $\nu$ is the viscosity of water. Due to the irregular shape of sediment particles, Stokes' equation cannot be used. Tsai (2000) considered the principle of superposition drag force and analyzed large amounts of measured data to compute the fall velocity as:

$$
\begin{aligned}
\omega_{s}= & \frac{1}{25.6}(s-1) g \frac{d^{2}}{\nu} \quad(d<0.1 \mathrm{~mm}) \\
\omega_{s}= & \sqrt{\left(13.95 \frac{\nu}{d}\right)^{2}+1.09(s-1) g d} \\
& -13.95 \frac{\nu}{d} \quad(0.1 \mathrm{~mm}<d<4 \mathrm{~mm}) \\
\omega_{s}= & 1.044 \sqrt{(s-1) g d} \quad(d>4 \mathrm{~mm})
\end{aligned}
$$

Equation (17) by Tsai and Tsai (2000) demonstrated that very high precision in computing the fall velocity.

\subsection{Numerical scheme}

\subsubsection{Water stage calculations}

The watershed must be divided into computational cells, according to topographic conditions and landforms. Each cell calculation is based on continuity equation such as equation (1) and discharge formula, equations (4, 5, 7 and 8). Water flow calculations of the model may be established for each cell to solve simultaneously the continuity equation and discharge formula. Equation (1) is a non-linear differential. Using a finite-difference scheme, equation (1) may be expressed as:

$$
A_{s i}^{j} \frac{\Delta h_{i}}{\Delta t}=P_{e i}^{j}+\sum Q_{i, k}
$$

where $A_{s i}^{j}, P_{e i}^{j}$ and $Q_{i, k}^{j}$ are the area of the $i$ th cell, effective rainfall volume in the $i$ th cell and flow exchange between $k$ th and $i$ th cell at time $j$ th. $\Delta t$ is time increment between $t^{j}$ and $t^{j+1} . \Delta h_{i}$ is water stage increment in the $i$ th cell at time between $t^{j}$ and $t^{j+1}$. Using finite differentiation, the water stage in the $i$ th cell at time $m$ may be expressed by equation (19):

$$
h_{i}^{m+1}=h_{i}^{m}+\frac{\left(\sum_{k} Q_{i, k}^{m}+P_{e i}^{m}\right)}{A_{s i}} \cdot \Delta t
$$

where $h_{i}^{m+1}$ is the water stage in the $i$ th cell at time $m+1 ; h_{i}^{m}$ is the water stage in the $i$ th cell at time $m ; Q_{i, k}$ is the discharge from the $k$ th cell into the $i$ th cell at time $m ; \Delta t$ is time increment between $t$ and $t+1$. The relationship between $Q_{i, k}, h_{i}$ and $h_{k}$ may be derived from equations $(4,5,7$, and $8)$. Water stage hydrographs may be obtained from equation (19) and the corresponding hydrological and physiographical data. The water depth in the $i$ th cell may be expressed as:

$$
D_{i}=h_{i}-z_{i}
$$

where $D_{i}$ is the water depth in the $i$ th cell; $z_{i}$ is the bed elevations in the $i$ th cell.

\subsubsection{Volumetric concentration of suspended sediment and bed variation}

For the $i$ th cell, the explicit finite differentiation representation by equation (9) is

$$
C_{i}^{m+1}=\frac{\left(\sum_{k} Q_{S C_{i, k}}^{m}+Q_{s e i}^{m}-Q_{s d i}^{m}+R_{D T i}^{m}\right)}{A_{i} D_{i}^{m+1}} \cdot \Delta t
$$

where $Q_{S C_{i, k}}$ is the sediment discharge between neighbouring $i$ th and $k$ th cells, and is determined by the direction of $Q_{i, k}$ that is the discharge from the $k$ th cell into the $k$ th cell. If the discharge flows from the $k$ th cell into the $i$ th cell, then $Q_{S C_{i, k}}=\left|Q_{i, k}\right| \times C_{k}$. Conversely, if the discharge flows from the $i$ th cell into the $k$ th cell, then $Q_{S C_{i, k}}=-\left|Q_{i, k}\right| \times C_{i}$. The values of $Q_{s e i}, Q_{s d i}$, and $R_{D T i}$ may be obtained from equations (11), (14) and (15). The value of $D_{i}$ may be obtained from equation (20).

\section{Study area}

This study was conducted at Agongdian reservoir in Kaohsiung city, southern Taiwan, where water is collected from the Joushui and Wanglai Rivers. The reservoir has a storage capacity of $28,256,500$ $\mathrm{m}^{3}$ and a water storage period from September 11 to May 31. The watershed area is $29.58 \mathrm{~km}^{2}$, with $12.81 \mathrm{~km}^{2}$ from the Joushui River watershed (43\%) and $16.77 \mathrm{~km}^{2}$ from the Wanglai River watershed 

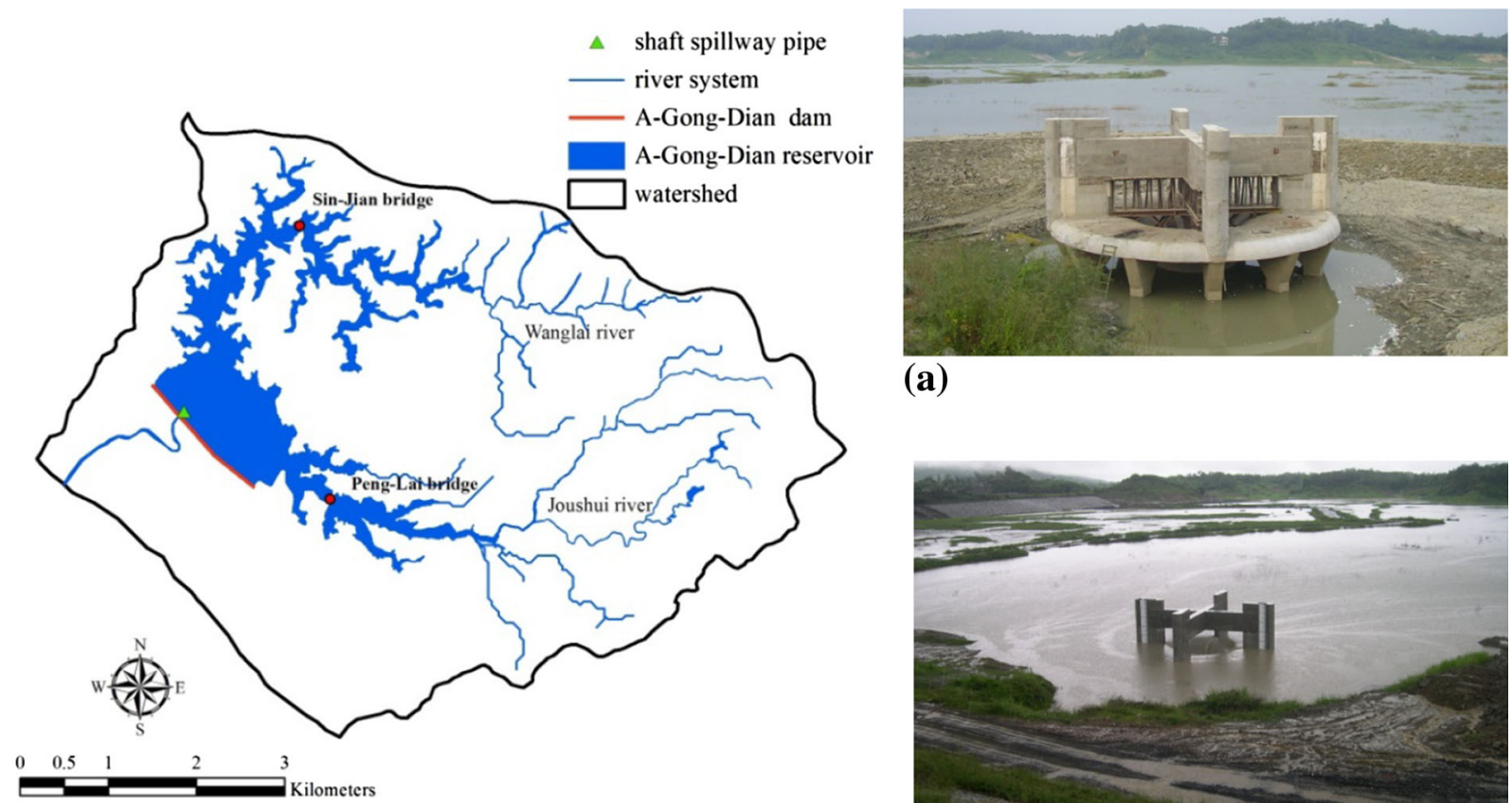

(a)

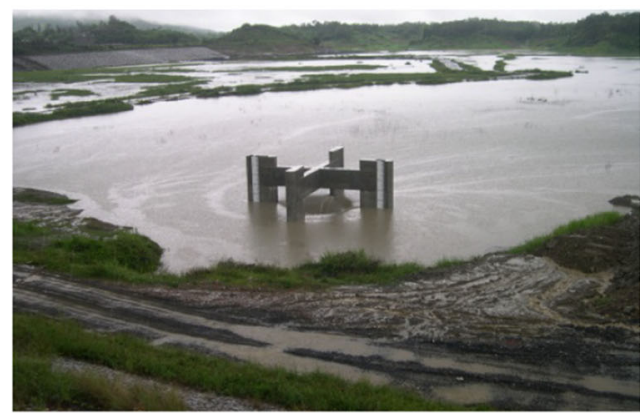

(b)

Figure 1. River system and Agongdian reservoir with shaft spillway shown in (a) and (b).

(57\%) (figure 1). The primary objective of reservoirs is to control floods, followed by water supply and irrigation purposes. Reducing sediment deposition in a reservoir is crucial for increasing storage; therefore, the method of sediment flushing with a shaft spillway pipe is often used during the wet period (June 1-September 10) to increase the effective storage capacity of the reservoir, as shown in figure 1. During sediment flushing operations, cross-basin diversion is used to promote the flushing of empty storage by irrigation and water supply purposes.

The elevation of the dam top, design water stage, and maximum water stage were 42,37 , and 40 $\mathrm{m}$, respectively. The Agongdian reservoir adopts a shaft spillway pipe $2.8 \mathrm{~m}$ in diameter to lower the pipe top elevation to $27 \mathrm{~m}$. Based on hydraulic model test results, the flow discharge of the shaft spillway pipe can be expressed as equations (22 and 23) (Southern Water Resources Bureau 2010)

Free overfall $Q=34.12(H-27)^{1.5}, \quad H \leq 28.57 \mathrm{~m}$

Pipe flow $Q=17.63(H-14)^{0.5}, \quad H>28.57 \mathrm{~m}$

where $H$ is the water stage in the reservoir and $Q$ is the releasing discharge. The maximum releasing discharge of pipe flow for the shaft spillway pipe is $89.90 \mathrm{~m}^{3} / \mathrm{s}$ when the water stage reaches the $40 \mathrm{~m}$ design maximum water stage.

\section{Applications of the GIS}

Because of variations in topography, landform, vegetation, and land use in the watershed, the runoff process caused by rainfall and the induced erosion vary in terms of time and space. To determine the runoff process, sediment yield, and soil erosion in the watershed, the computational cells are divided based on the topography and landform. The topography of Taiwan is very complex and large quantities of hydrological and geographic data have been generated. To analyze these data, ArcMap and Arc/Info in the GIS were applied. The extensive moduli of ArcMap include spatial analysis, a hydrologic model, 3D analysis, network analysis, and object-oriented programming. Based on the river line and flow direction, the subwatersheds can be automatically generated using a digital elevation model (DEM). In this study, a $5 \times 5 \mathrm{~m}$ resolution DEM was used (figure 2).

In subwatersheds, river cells are created after the width has been determined from cross-section measurements. Land cells can be generated through overlaying of the digitized maps of soil, land use, and road systems. Finally, the small and slim cells 


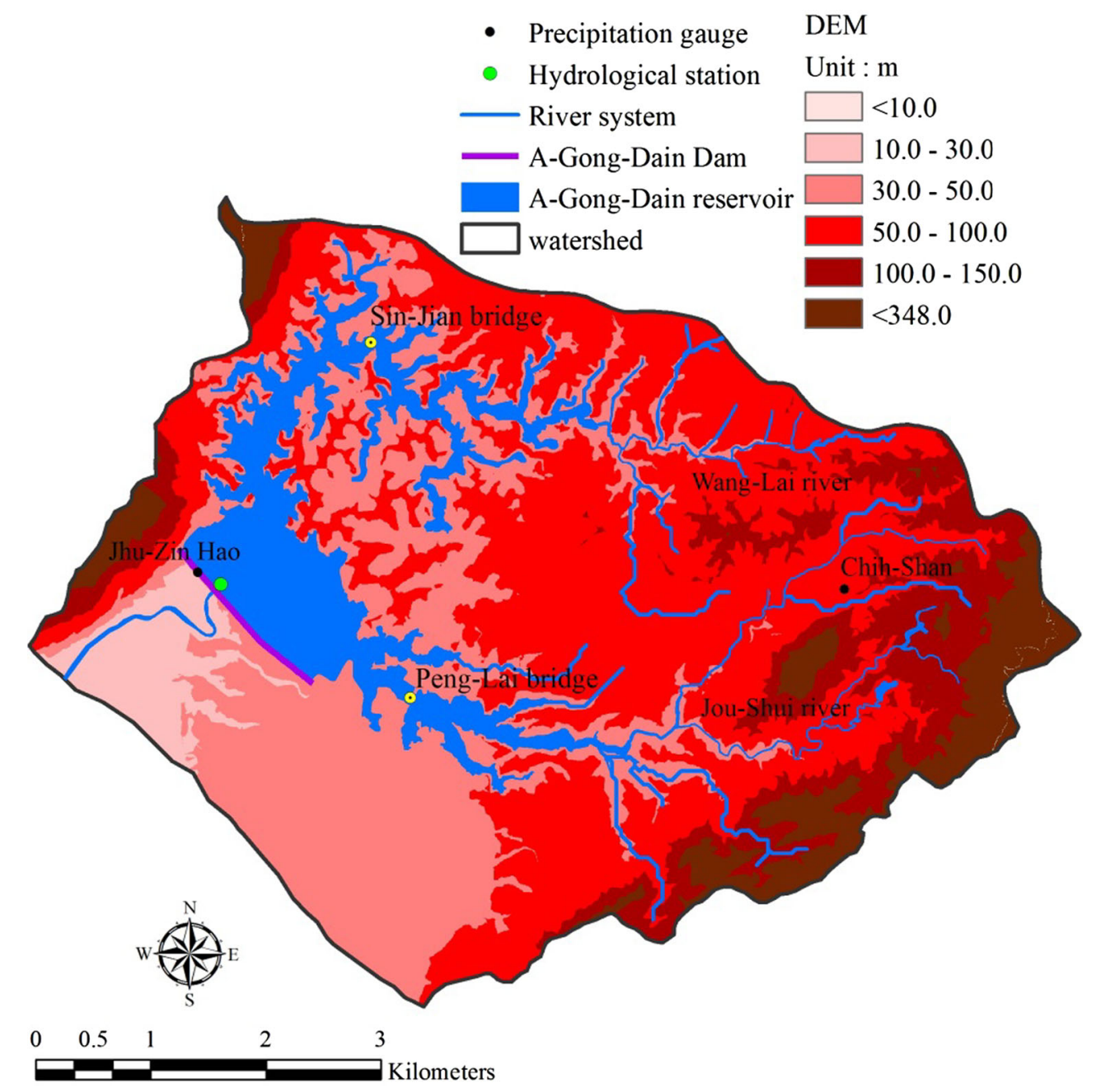

Figure 2. Surface elevation, precipitation gauge stations, and hydrological station of Agongdian reservoir.

are separately merged with the large cells and the new cells are subdivided into groups of appropriate cell size to complete the generation of computational cells, as shown in figure 3. In total, 4595 computational cells were generated in this study. Hydrologic and physiographic data obtained from the GIS were used as input data for the soil erosion-deposition model to simulate water flow and sediment transport processes.

\subsection{Hydrological and physiographic data of Agongdian reservoir watershed}

The watershed has two precipitation gauge stations: Chin-Shan and Jhu-Zih-Jiao (figure 2). Data observed from these gauge stations were used to simulate storm events and verify and analyze design rainfall events of 1 - and 2-day storms for various return periods. The watershed has a single hydrological station (figure 2) located near the shaft spillway pipe.
Table 1 lists the values of Manning's roughness coefficient and coverage factor for each type of vegetation and land use, respectively. Similarly, the physiographic properties of land use and vegetation in each cell were captured by overlaying the land use map (figure 4) with the cell map. Using these physiographic properties and the data in table 1 , we obtained the Manning's roughness coefficient and coverage factor for each cell. In addition, upon overlaying the soil map with the cell map, the representative soil particle diameter for each land cell was obtained. In each river cell, the representative diameter of the soil particles is based on the measured data.

\subsection{Calculation procedures for the GIS and PSED model}

The procedure for linking the PSED model and GIS to obtain the required hydrographs, sediment yield, and sediment flushing data is shown in 


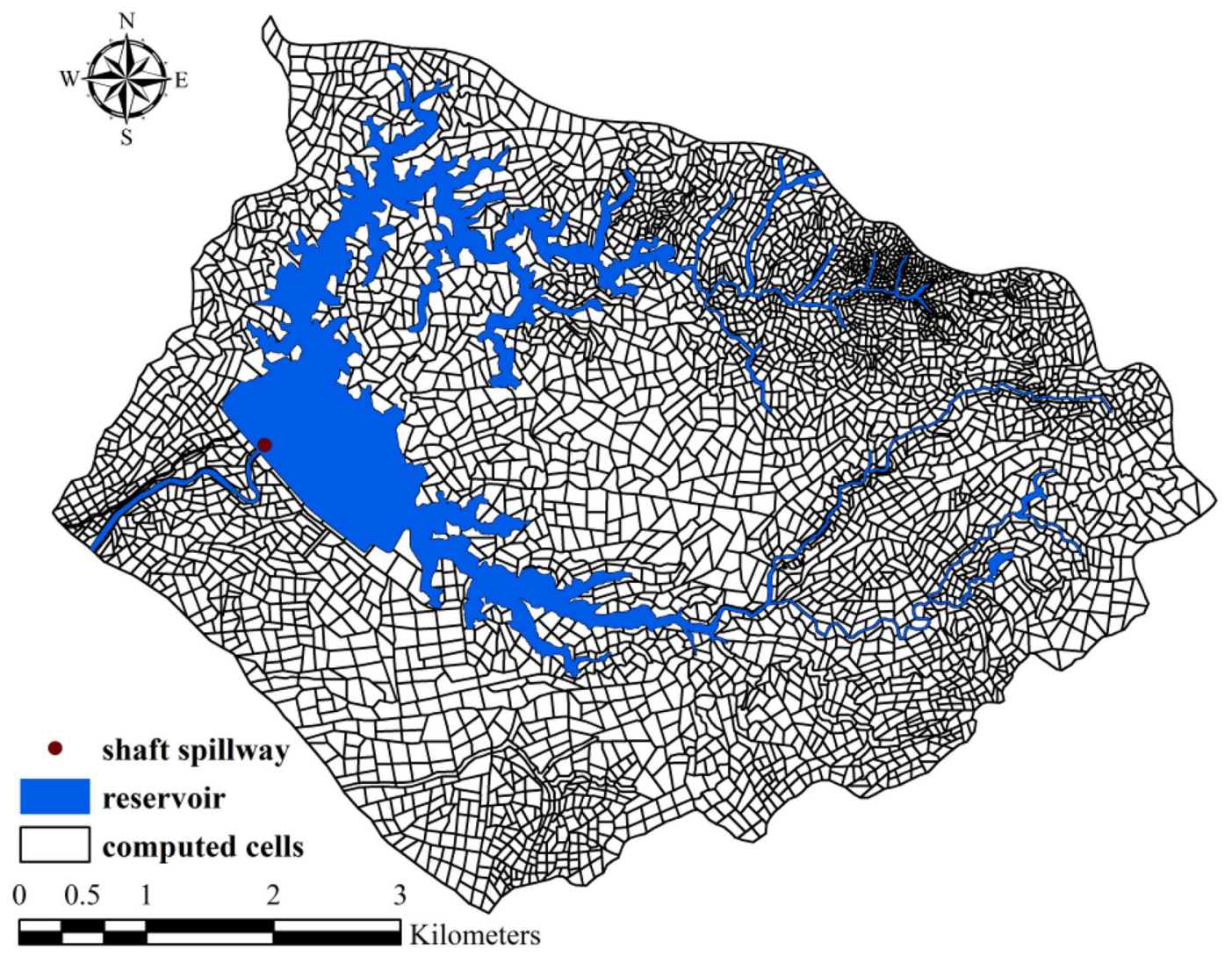

Figure 3. Computed cells in Agongdian reservoir watershed.

Table 1. Manning's roughness coefficients of overland flow and cover management factors for various land uses (Chen et al. 2011).

\begin{tabular}{lcc}
\hline Land use & $\begin{array}{c}\text { Manning's roughness } \\
\text { coefficient }\end{array}$ & $\begin{array}{c}\text { Cover management } \\
\text { factor } c^{\prime}\end{array}$ \\
\hline Lawns & 0.35 & 0.05 \\
Without conservation & 0.20 & 1.00 \\
$\quad$ treatment & & \\
Concrete land & 0.10 & 0.00 \\
River & 0.05 & 0.00 \\
Reservoir & 0.03 & 0.00 \\
Rice paddy & 0.10 & 0.10 \\
Xerophyte & 0.35 & 0.25 \\
Orchard & 0.40 & 0.20 \\
Wood & 0.30 & 0.01 \\
Forest & 0.35 & 0.01 \\
Building & 0.10 & 0.01 \\
\hline
\end{tabular}

figure 5. The overall process of the simulation is detailed as follows:

(a) The GIS is used to partition the river watershed into overland, river channel, and reservoir cells.

(b) The functions of the GIS are used to analyze the hydrological and physiographical data, including rainfall, curve number, vegetation, land utilization, geometry, topology, cell elevation, weir variables, and initial conditions. The variables are analyzed and stored in a database.

(c) Input files for the PSED model are prepared using the database in step b.

(d) Flow calculations are performed using equations (19) and (20) to obtain the flow depth in each cell. 


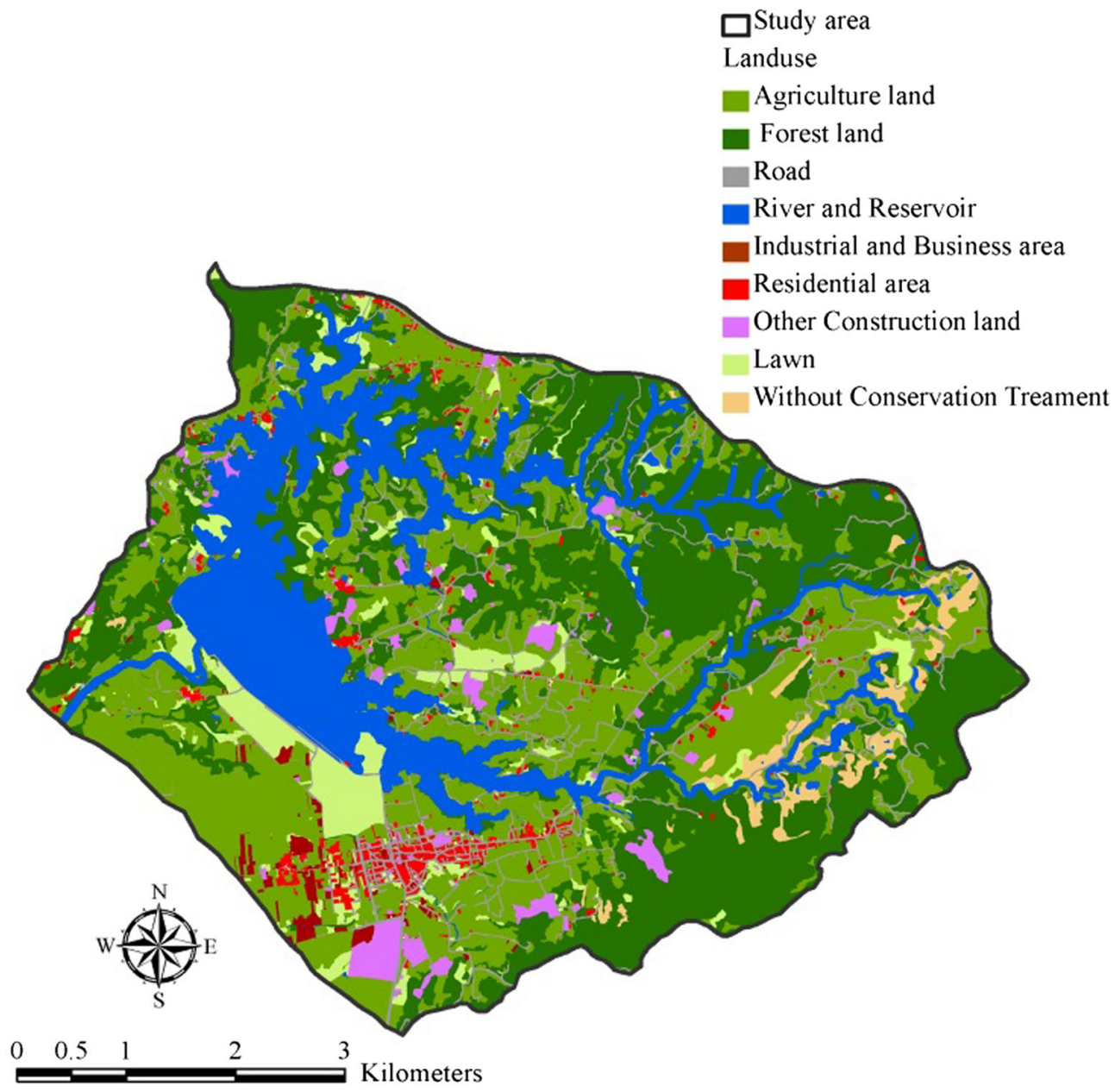

Figure 4. Land uses of Agongdian reservoir watershed.

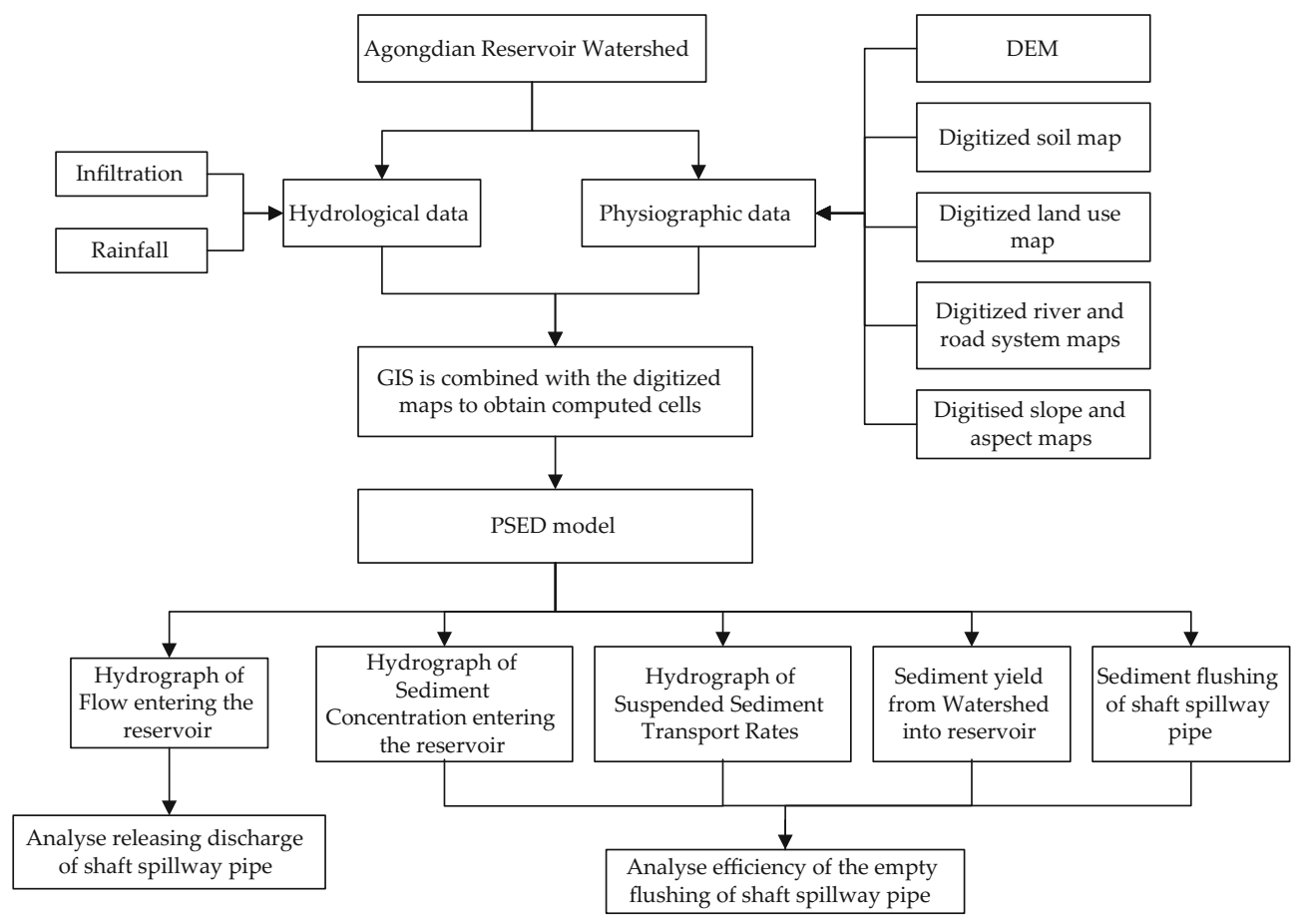

Figure 5. Simulation process of PSED model. 


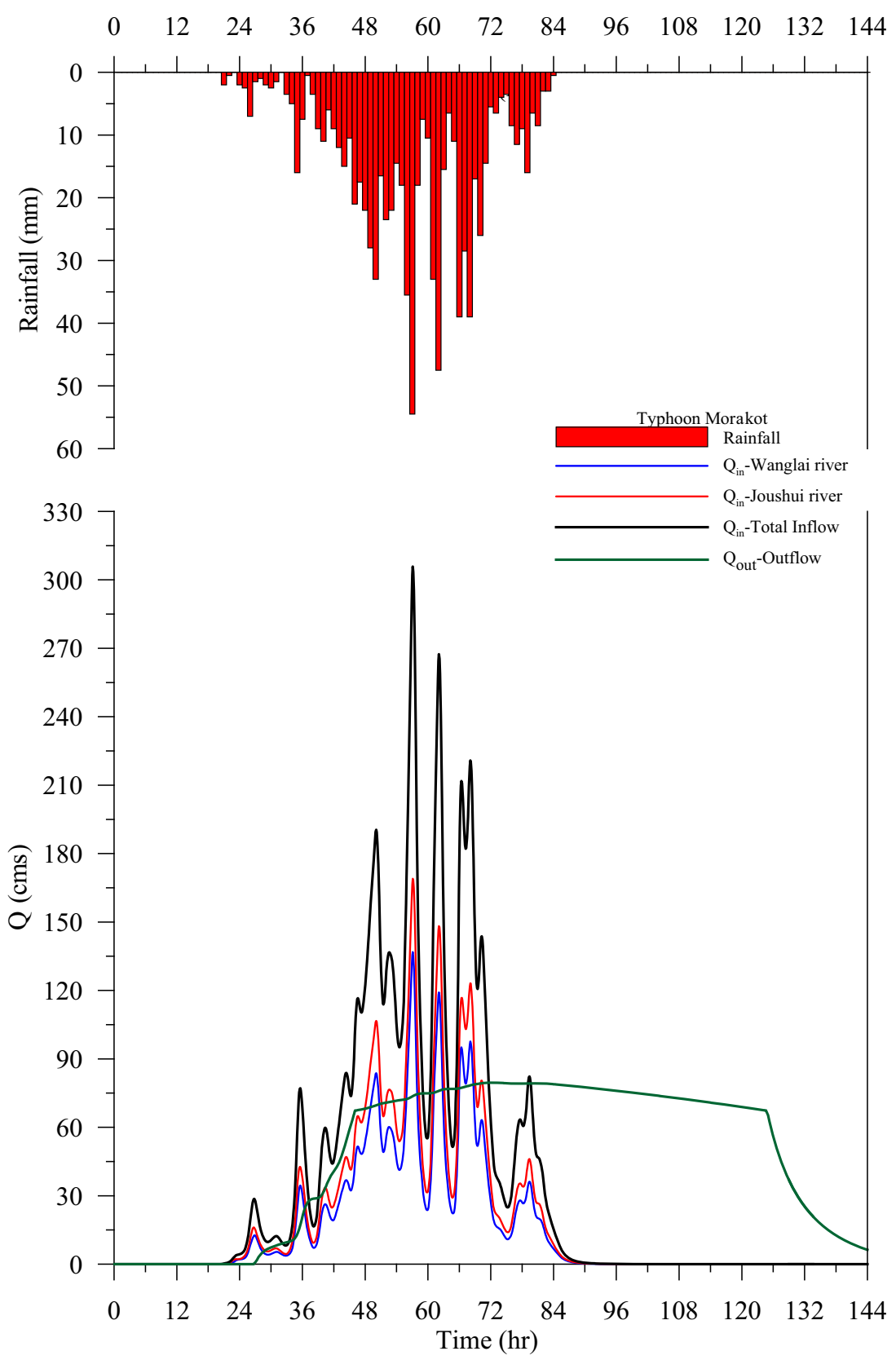

Figure 6. Simulated inflow and outflow discharge during Typhoon Morakot.

(d) Soil erosion-deposition calculations are performed using equation (21) to obtain the volumetric concentration of suspended sediment in each cell.

(f) Steps d and e are repeated for rainfall duration.

\section{Model verification}

Rainfall, flow discharge entering the reservoir, and the flushing volume of reservoirs are crucial factors for flood control operation strategies. In this study, the PSED simulation results were compared with the observed data. In addition, reservoir operations data and reservoir sediment measurements were analyzed. To verify the model, reasonable simulations of the inflow hydrograph and suspended sediment concentration hydrographs are sought.

\subsection{Simulation and verification of the hydrograph for flow entering the reservoir}

Typhoon Morakot of 2009 was used as a case study for simulating the inflow hydrograph (flow entering the reservoir), sediment concentration 


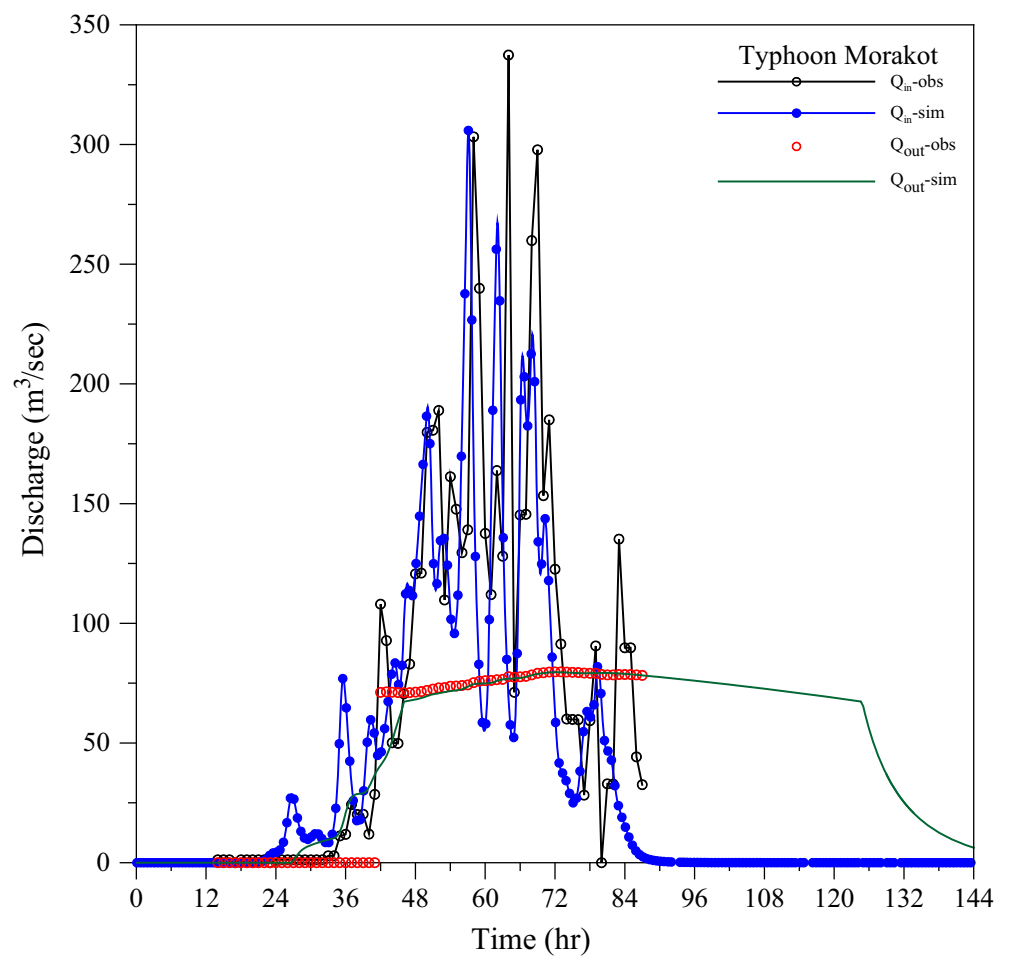

Figure 7. Comparison of simulated and observed discharge during Typhoon Morakot.

hydrograph entering the reservoir, suspended sediment transport rate hydrograph, sediment yield from the watershed into the reservoir, and sediment flushing of the shaft spillway. The simulation results of the PSED model alongside the observed data are shown in figures 6 and 7 . The results indicated a good fit for the hydrograph of flow entering the reservoir. The simulated and observed maximum inflow figures were 305.80 and $337.38 \mathrm{~cm}$, respectively. The simulated and observed total inflow volume figures were $18,076,869$ and 20,865,090 $\mathrm{m}^{3}$, respectively, and these figures translate to simulation relative errors of 9.36 and $13.36 \%$ for the maximum and total inflow, respectively.

\subsection{Simulation and verification of inflow and outflow suspended sediment transport rates}

In most cases, monitoring of suspended sediment concentration in rivers is always minimal because of the costs involved. Therefore, negligible data were available for the model verification in our study. Figure 8 shows the simulation of inflow and outflow suspended sediment transport rates during Typhoon Morakot in 2009. The PSED calculated sediments into the reservoir are shown in table 2. The results indicate that $67.15 \%$ of the sediment was from Joushui River watershed and $32.85 \%$ was from Wanglai River watershed. According to the results of the local government report (Water Resources Planning Institute 2003), 72 and 28\% of the sediment yield is from the Joushui and Wanglai River watersheds, respectively. The results correspond to those of the hydraulic model test conducted in the laboratory. Therefore, this model can be used to accurately estimate the inflow and outflow suspended sediment concentration hydrograph and sediment flushing via the shaft spillway in the study area.

\section{Results and discussion}

In this study, the design rainfall of 1- and 2-day storms for various return periods $(2,5,10,25$, 50,100 , and 200 yrs) were analyzed by the Water Resources Agency according to the design rainfall events of simulation cases. The PSED model was then applied to simulate and calculate the inflow and outflow hydrographs of flow, sediment, and the sediment flushing efficiency of empty storage under the conditions of various design rainfall events.

\subsection{Simulation of inflow discharge and suspended sediment for Agongdian reservoir}

The inflow discharge hydrographs from the Joushui and Wanglai River watersheds were calculated under the conditions of 1- and 2-day storms for 


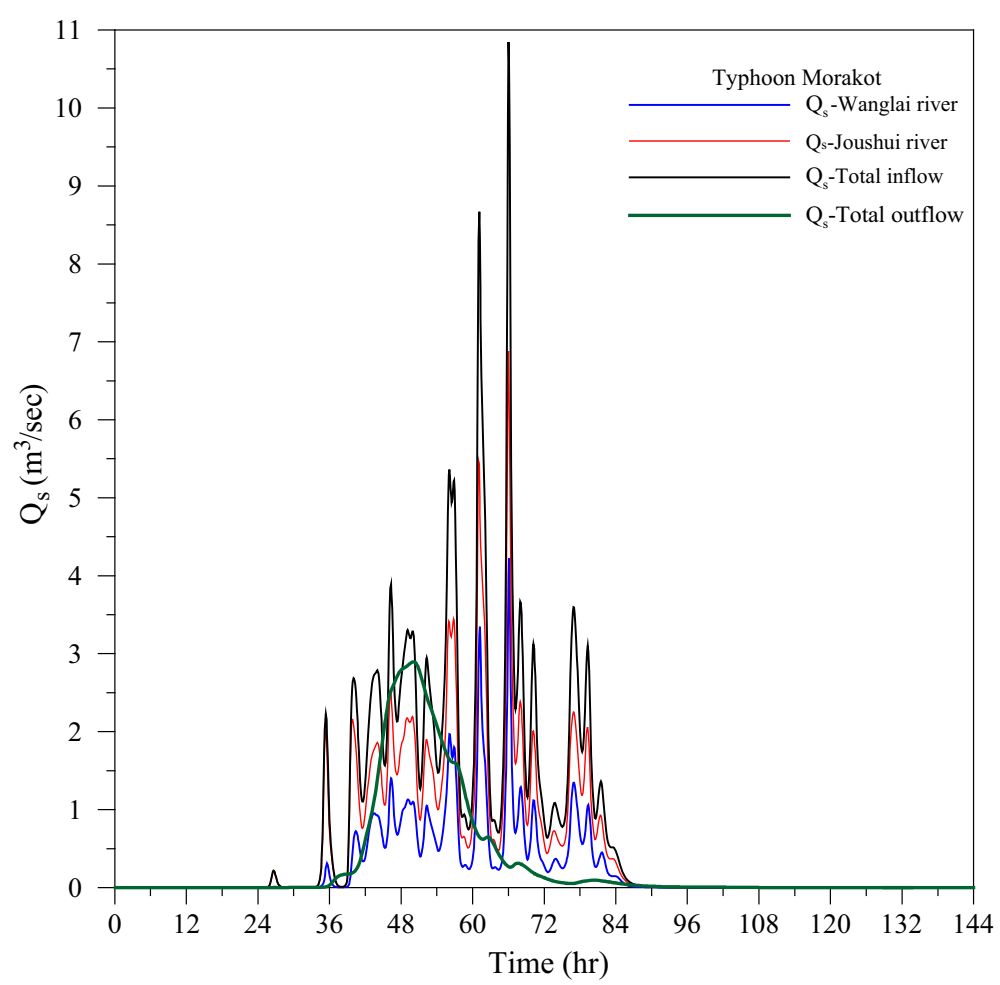

Figure 8. Simulated inflow and outflow suspended sediment transport rate during Typhoon Morakot.

Table 2. Sediment yield from the watershed into the reservoir.

\begin{tabular}{|c|c|c|c|c|}
\hline \multirow[b]{2}{*}{ Typhoon event } & \multicolumn{2}{|c|}{ Joushui river subwatershed } & \multicolumn{2}{|c|}{ Wanglai river subwatershed } \\
\hline & $\begin{array}{l}\text { Sediment yield } \\
\text { into reservoir } \\
\left(\mathrm{m}^{3}\right)\end{array}$ & $\begin{array}{l}\text { Percentage of the } \\
\text { sediment yield } \\
\text { into reservoir }(\%)\end{array}$ & $\begin{array}{l}\text { Sediment yield } \\
\text { into reservoir } \\
\qquad\left(\mathrm{m}^{3}\right)\end{array}$ & $\begin{array}{l}\text { Percentage of the } \\
\text { sediment yield } \\
\text { into reservoir }(\%)\end{array}$ \\
\hline Typhoon Morakot & 258200 & 67.15 & 126341 & 32.85 \\
\hline Typhoon Fanapi & 146474 & 69.35 & 64730 & 30.65 \\
\hline
\end{tabular}

seven return periods $(2,5,10,25,50,100$, and 200 yrs) and accumulated inflow discharge to obtain the total flow discharge into the reservoir. The results are shown in figures 9 and 10. Figures 11 and 12 show the hydrographs for the suspended sediment transport rate into the reservoir during the 1- and 2-day storms for all return periods. Tables 3 and 4 show the soil erosion and sediment yield of the reservoir watershed.

The results indicate that sediment yield from the Joushui River watershed was approximately 2.31 times higher than that from the Wanglai River watershed. According to a Taiwan Water Resources Agency research report (Water Resources Planning Institute 2003), 72 and $28 \%$ of the sediment yield was from the Joushui and Wanglai River watersheds, respectively. The findings of this study indicate that the amounts of sediment yield for the 1- and 2-day storms were on average 69.75 and $70.64 \%$, respectively, for the Joushui River watershed and 30.25 and $29.36 \%$, respectively, for the Wanglai River watershed. For both storms, the PSED simulated results correspond with those of the Water Resources Agency report (Water Resources Planning Institute 2003).

\subsection{Simulation of empty flushing efficiency}

To understand the discharge release of the shaft spillway pipe during the flooding period, the PSED model was applied to simulate the inflow discharge into the reservoir under the conditions of 1- and 2-day storms for seven return periods, as illustrated in figures 9 and 10. Because the maximum 


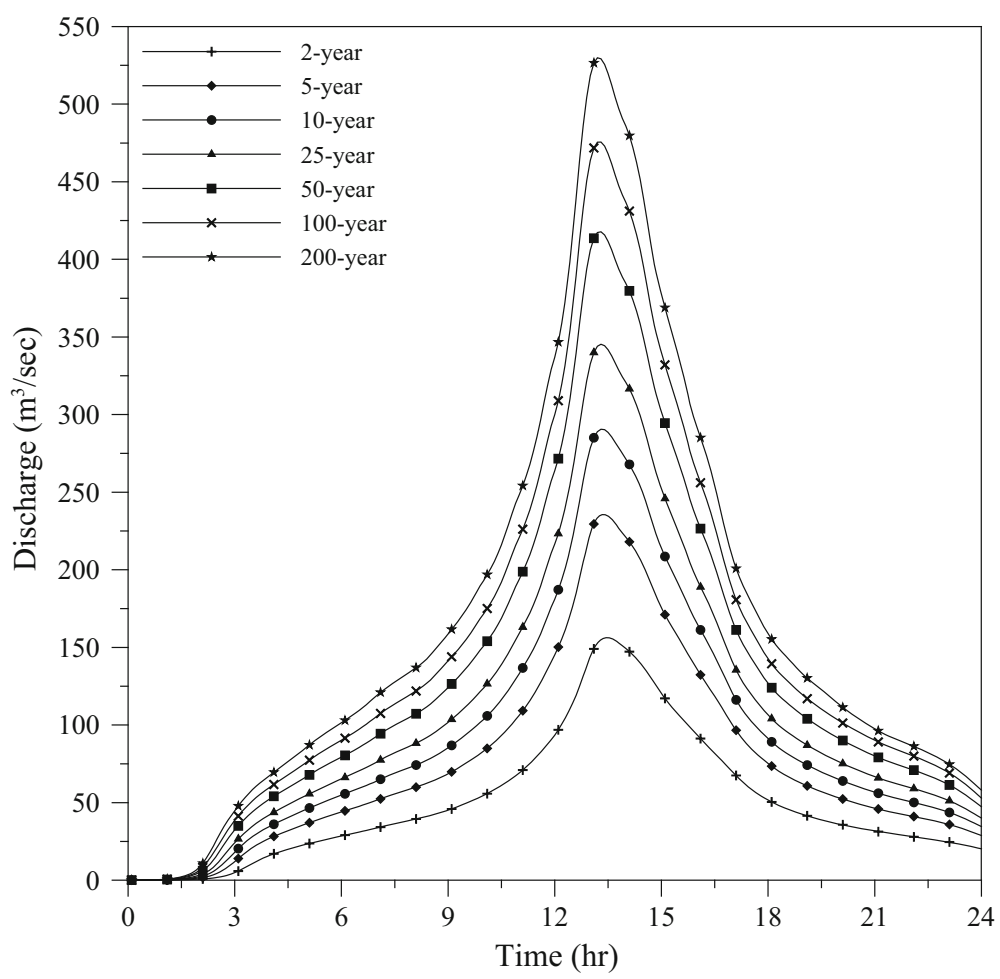

Figure 9. Hydrograph of 1-day flow discharge into the reservoir.

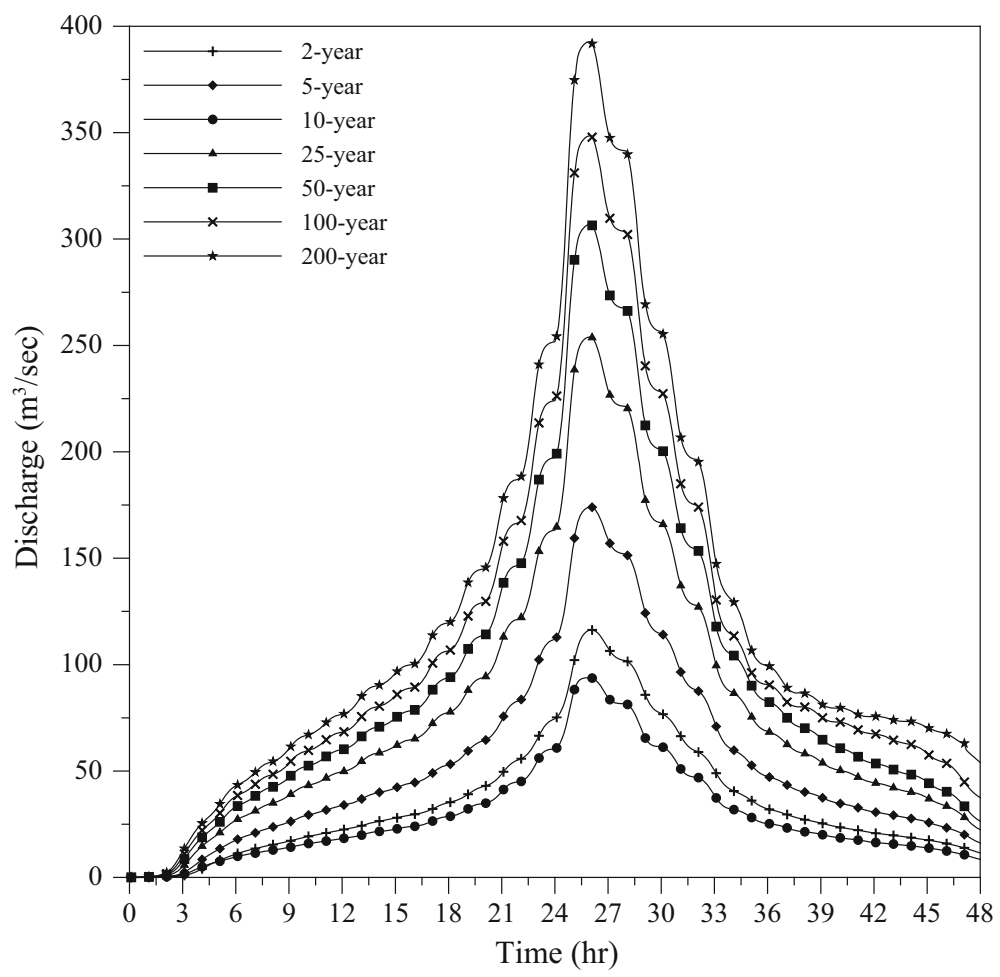

Figure 10. Hydrograph of 2-day flow discharge into the reservoir.

discharge release of the shaft spillway pipe is 89.90 $\mathrm{m}^{3} / \mathrm{s}$, the flow discharge entering the reservoir is usually greater than $85 \mathrm{~m}^{3} / \mathrm{s}$. Although the shaft spillway pipe released discharge, the inflow discharge was several times higher than the released discharge, especially toward the peak flow. Therefore, the water stage continued to rise in the reservoir. Figures 13 and 14 indicate the presence 

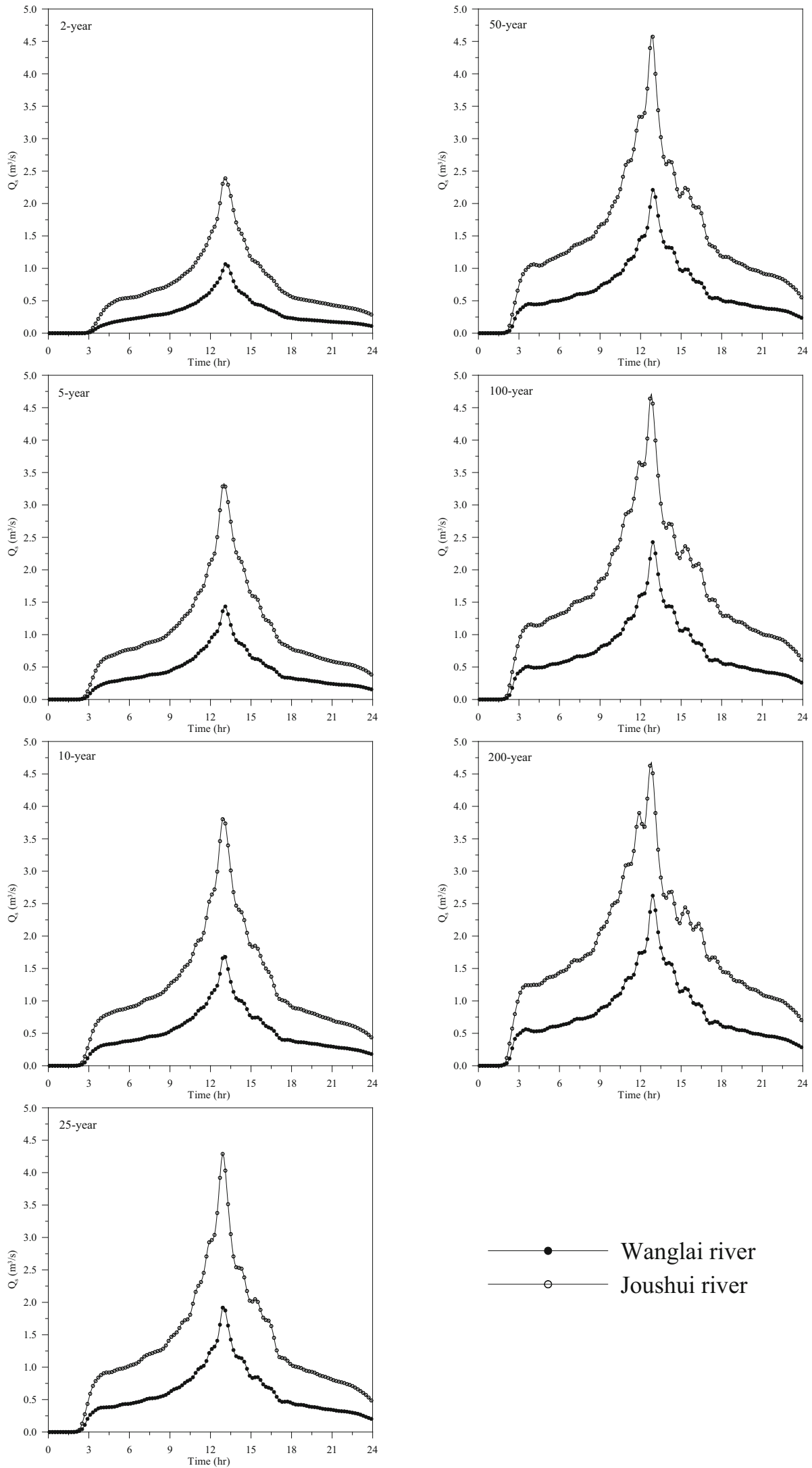

Figure 11. Hydrographs for suspended sediment transport rate into the reservoir under the conditions of the 1-day storm. 

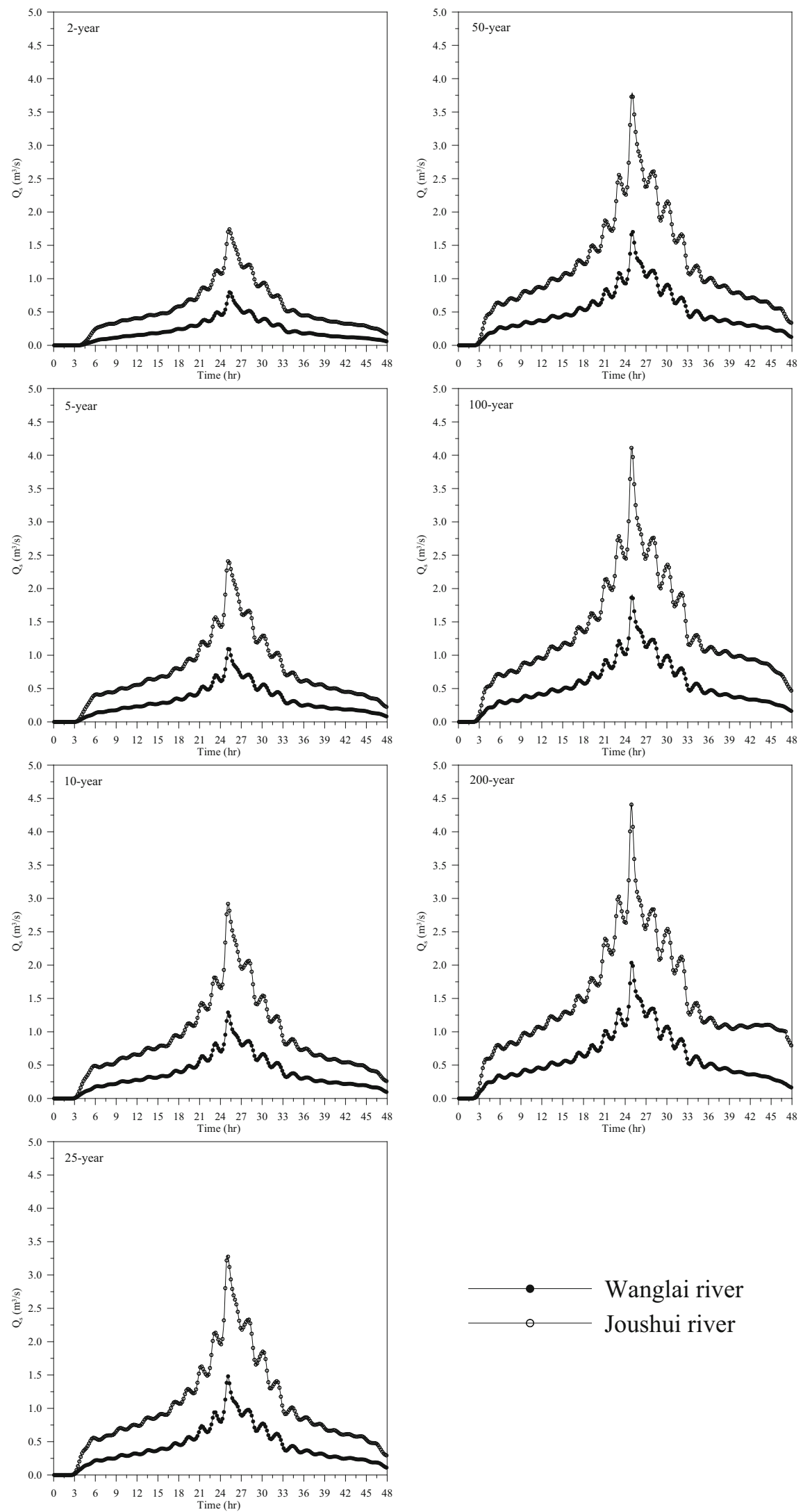

Joushui river

Figure 12. Hydrographs for suspended sediment transport rate into the reservoir under the conditions of the 2-day storm. 
Table 3. Soil erosion and sediment yield in the 1-day storm for all return periods.

\begin{tabular}{|c|c|c|c|c|c|c|}
\hline \multirow{2}{*}{$\begin{array}{l}\text { Return } \\
\text { period }\end{array}$} & \multirow{2}{*}{$\begin{array}{l}\text { Total soil } \\
\text { erosion } \\
\left(\mathrm{m}^{3}\right)\end{array}$} & \multicolumn{3}{|c|}{$\begin{array}{l}\text { Amount of sediment yield from } \\
\text { subwatershed into reservoir }\left(\mathrm{m}^{3}\right)\end{array}$} & \multicolumn{2}{|c|}{$\begin{array}{c}\text { Percentage of sediment yield } \\
\text { from subwatershed into reservoir }(\%)\end{array}$} \\
\hline & & Wanglai river & Joushui river & Total & Wanglai river & Joushui river \\
\hline $2 \mathrm{yr}$ & 273693 & 25466 & 61290 & 86756 & 29.35 & 70.65 \\
\hline $5 \mathrm{yr}$ & 345673 & 35733 & 85382 & 121115 & 29.50 & 70.50 \\
\hline $10 \mathrm{yr}$ & 389478 & 42375 & 100253 & 142628 & 29.71 & 70.29 \\
\hline $25 \mathrm{yr}$ & 430723 & 48587 & 113072 & 161658 & 30.06 & 69.94 \\
\hline 50 yr & 485181 & 56305 & 127685 & 183990 & 30.60 & 69.40 \\
\hline $100 \mathrm{yr}$ & 524436 & 61991 & 138057 & 200048 & 30.99 & 69.01 \\
\hline 200 yr & 562666 & 67808 & 147250 & 215058 & 31.53 & 68.47 \\
\hline
\end{tabular}

Table 4. Soil erosion and sediment yield in the 2-day storm for all return periods.

\begin{tabular}{|c|c|c|c|c|c|c|}
\hline \multirow{2}{*}{$\begin{array}{l}\text { Return } \\
\text { period }\end{array}$} & \multirow{2}{*}{$\begin{array}{c}\text { Total soil } \\
\text { erosion } \\
\left(\mathrm{m}^{3}\right)\end{array}$} & \multicolumn{3}{|c|}{$\begin{array}{l}\text { Amount of sediment yield from } \\
\text { subwatershed into reservoir }\left(\mathrm{m}^{3}\right)\end{array}$} & \multicolumn{2}{|c|}{$\begin{array}{c}\text { Percentage of sediment yield } \\
\text { from subwatershed into reservoir }(\%)\end{array}$} \\
\hline & & Wanglai river & Joushui river & Total & Wanglai river & Joushui river \\
\hline $2 \mathrm{yr}$ & 443955 & 37269 & 91929 & 129199 & 28.85 & 71.15 \\
\hline $5 \mathrm{yr}$ & 557444 & 52963 & 127535 & 180498 & 29.34 & 70.66 \\
\hline $10 \mathrm{yr}$ & 627812 & 63045 & 151082 & 214128 & 29.44 & 70.56 \\
\hline $25 \mathrm{yr}$ & 701289 & 72652 & 173346 & 245998 & 29.53 & 70.47 \\
\hline $50 \mathrm{yr}$ & 793946 & 84612 & 199903 & 284515 & 29.74 & 70.26 \\
\hline $100 \mathrm{yr}$ & 862089 & 94171 & 224686 & 318857 & 29.53 & 70.47 \\
\hline 200 yr & 918677 & 102636 & 249963 & 352599 & 29.11 & 70.89 \\
\hline
\end{tabular}

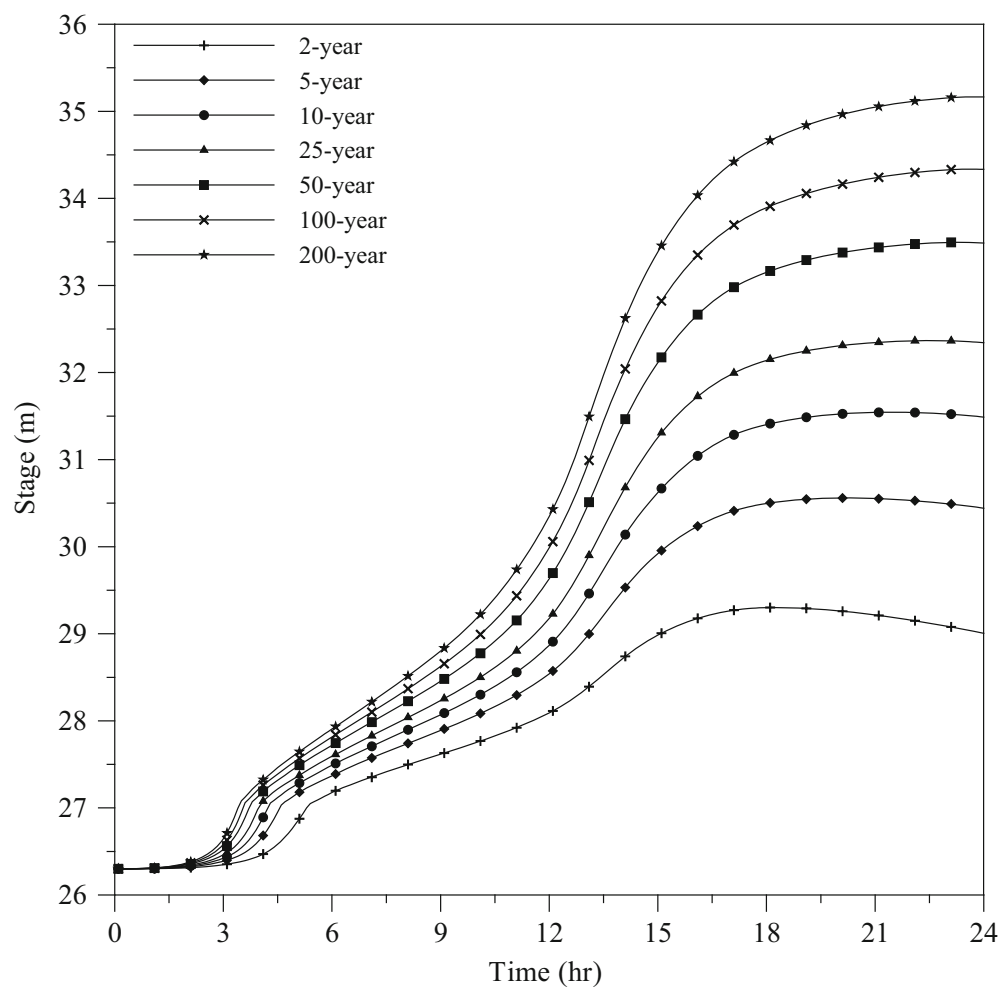

Figure 13. Hydrograph of 1-day simulation of water stage in the reservoir. 


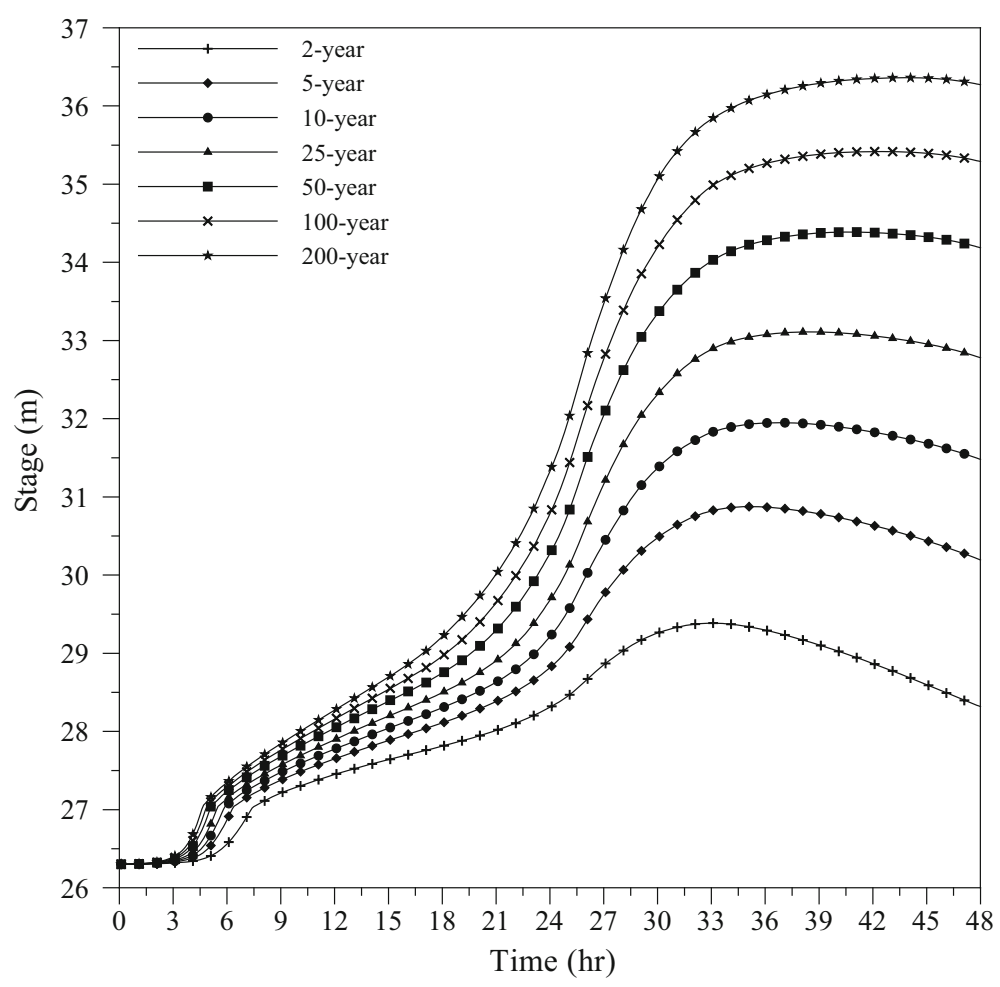

Figure 14. Hydrograph of 2-day simulation of water stage in the reservoir.

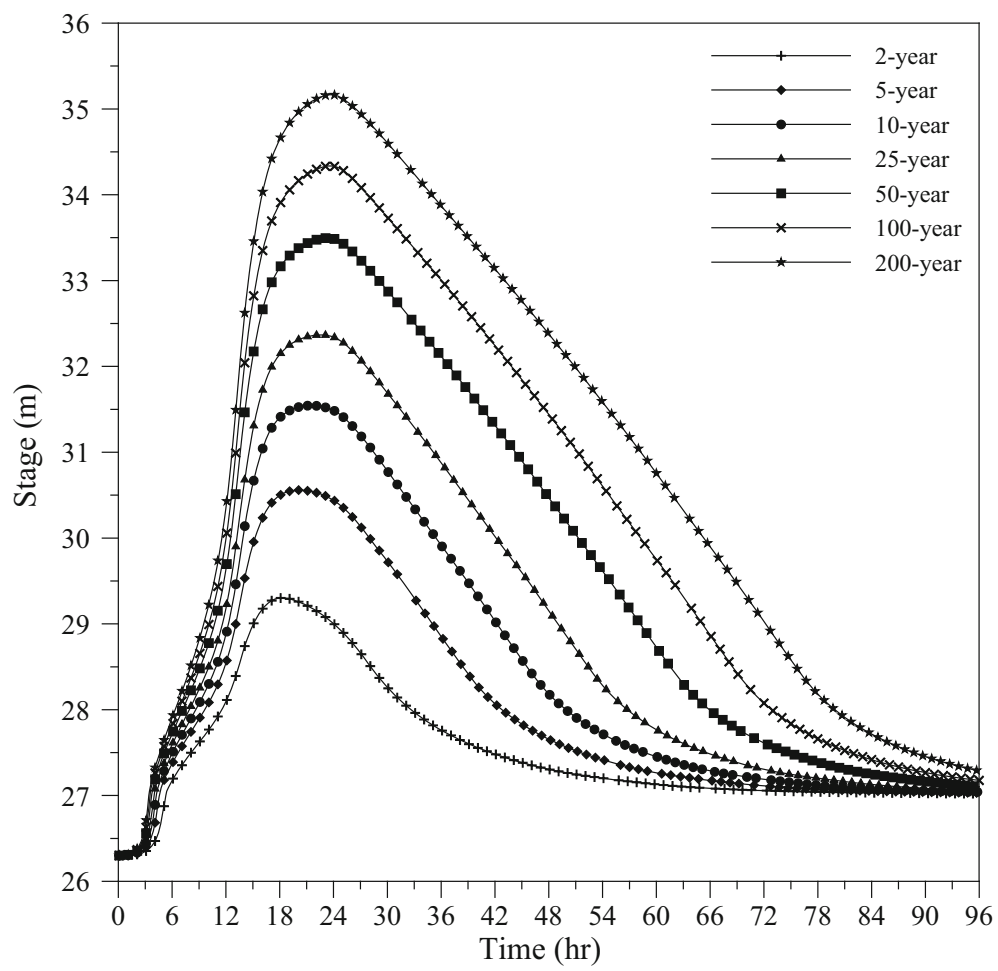

Figure 15. Hydrograph of 1-day simulation of water stage (duration: 4 days) in the reservoir.

of considerable water in the reservoir, even after the rain had stopped.

To understand the continuous release of discharge from the shaft spillway pipe after the rain had stopped, the amount of time required for the water stages to drop to the spillway pipe elevation of $27 \mathrm{~m}$ should be considered. In this study, after the rain had stopped, 3 days of sustained 


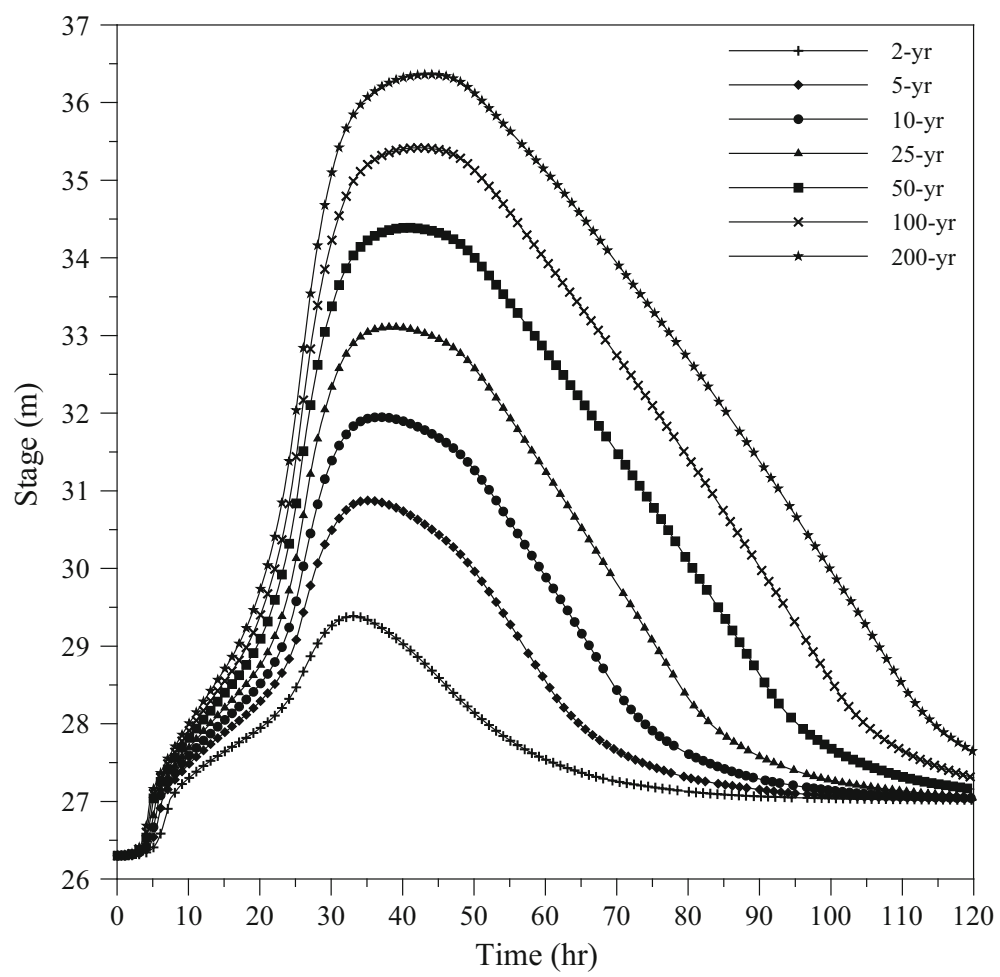

Figure 16. Hydrograph of 2-day simulation of water stage (duration: 5 days) in the reservoir.

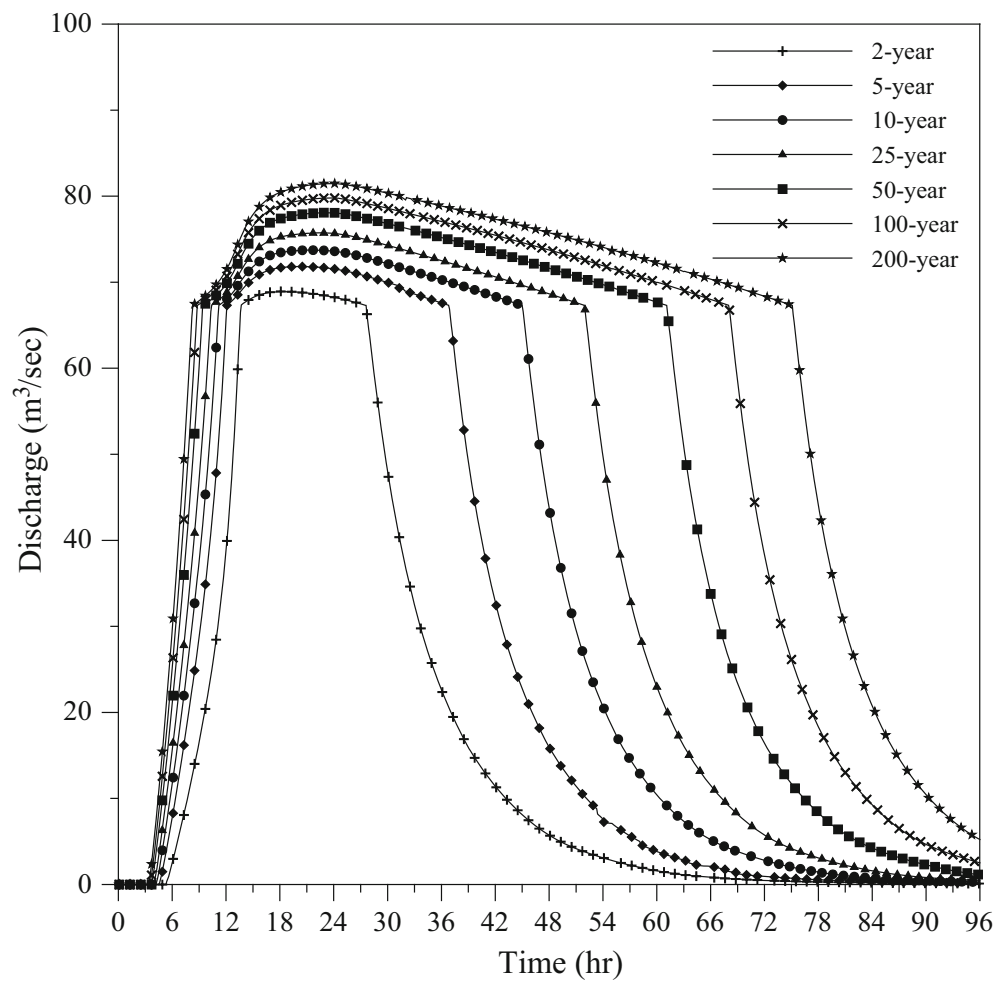

Figure 17. Hydrograph of 1-day simulation of outflow discharge for the shaft spillway (duration: 4 days) in the reservoir.

discharge was allowed. Thus, the water stage in the reservoir slowly dropped, as shown in figures 15 and 16. The figures indicate that during heavy storms (such as those for the 100- and 200-yr return periods), the water stage in the reservoir remained higher than $27 \mathrm{~m}$ after the rain had stopped and continuous 3-day discharge was allowed. This indicates that a longer time 


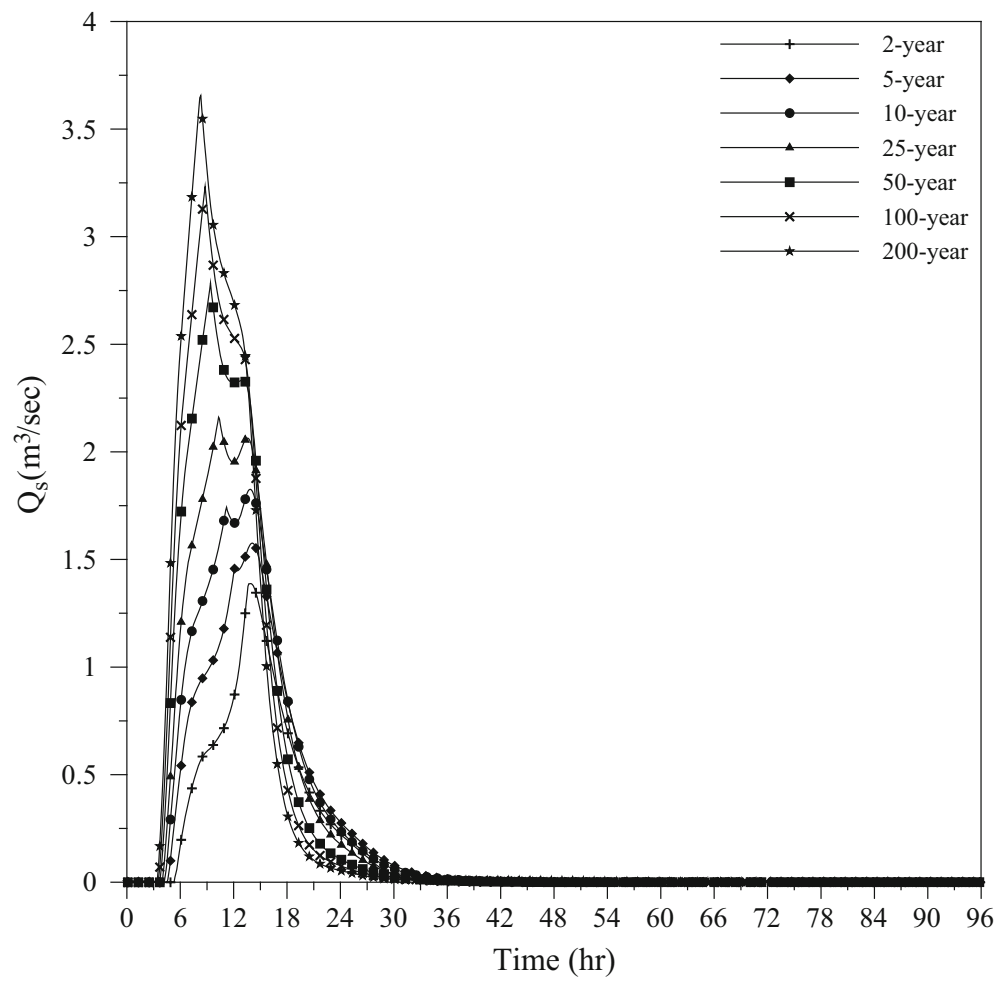

Figure 18. Hydrograph of 1-day simulation of suspended sediment for the shaft spillway (duration: 4 days) in the reservoir.

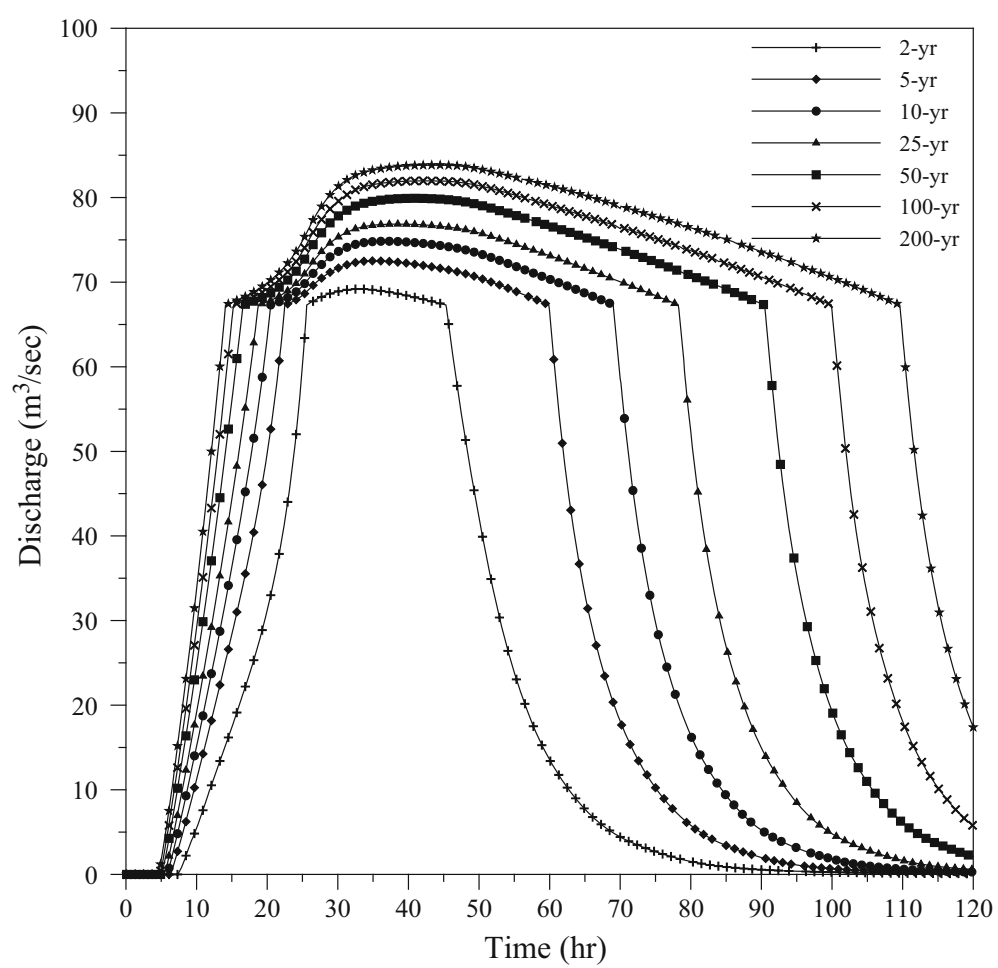

Figure 19. Hydrograph of 2-day simulation of outflow discharge for the shaft spillway (duration: 5 days) in the reservoir.

was required for release until the reservoir was completely empty.

The outflow discharge hydrographs and suspended sediment transport rate of the shaft spillway pipe were simulated under the conditions of the 1- and 2-day storms, as shown in figures 1720 . The peaks of the 1-day rainfall and the inflow discharge into the reservoir occurred at the 12th 


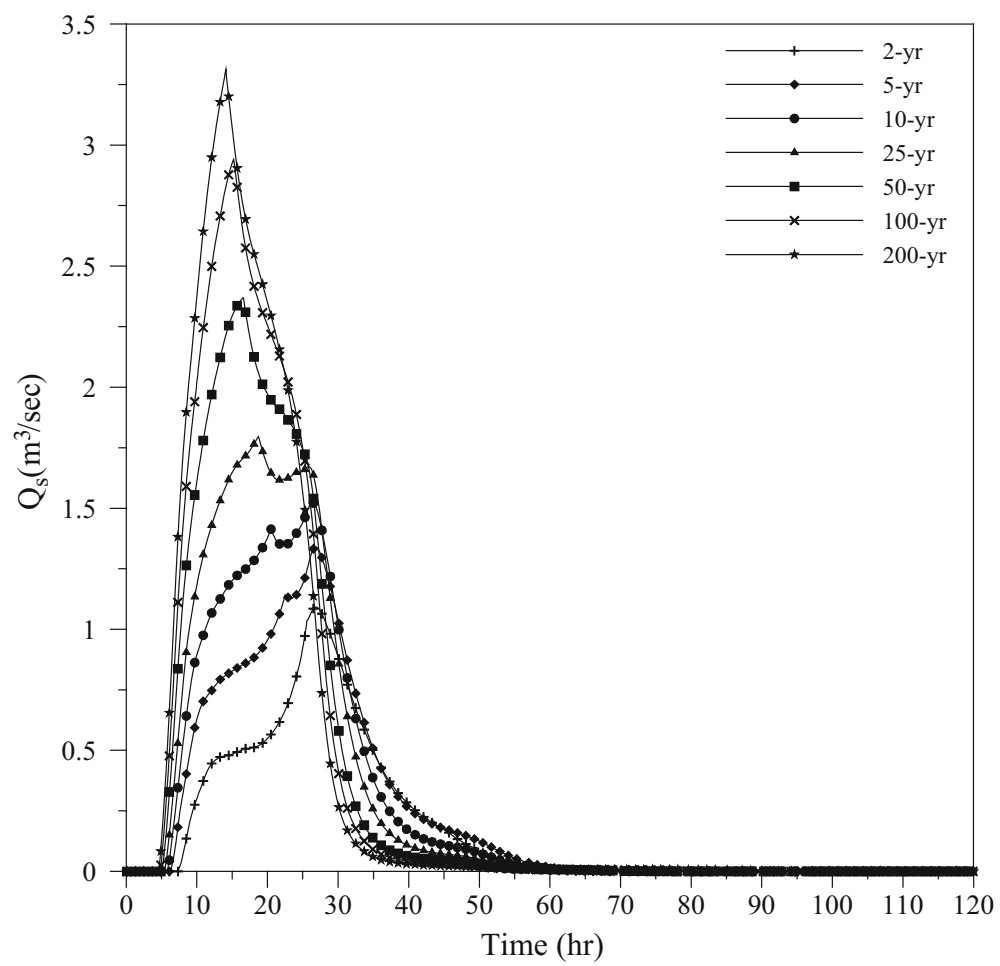

Figure 20. Hydrograph of 1-day simulation of suspended sediment for the shaft spillway (duration: 5 days) in the reservoir.

Table 5. Inflow and outflow suspended sediment transport rate during the 1-day storm.

\begin{tabular}{lcrrr}
\hline & \multicolumn{2}{c}{ Sediment yield of the watershed } & & \multicolumn{2}{c}{ Sediment flushing by the shaft spillway } \\
\cline { 2 - 3 } $\begin{array}{l}\text { Return } \\
\text { period }\end{array}$ & $\begin{array}{c}\text { Total soil } \\
\text { erosion }\left(\mathrm{m}^{3}\right)\end{array}$ & $\begin{array}{c}\text { Total sediment } \\
\text { yield }\left(\mathrm{m}^{3}\right)\end{array}$ & $\begin{array}{c}\text { Sediment } \\
\text { flushing }\left(\mathrm{m}^{3}\right)\end{array}$ & $\begin{array}{c}\text { Sediment flushing } \\
\text { efficiency }(\%)\end{array}$ \\
\hline $2 \mathrm{yr}$ & 273693 & 86756 & 47778 & 55.07 \\
$5 \mathrm{yr}$ & 345673 & 121115 & 66536 & 54.94 \\
$10 \mathrm{yr}$ & 389478 & 142628 & 78250 & 54.86 \\
$25 \mathrm{yr}$ & 430723 & 161658 & 88416 & 54.69 \\
$50 \mathrm{yr}$ & 485181 & 183990 & 99887 & 54.29 \\
$100 \mathrm{yr}$ & 524436 & 200048 & 107102 & 53.54 \\
$200 \mathrm{yr}$ & 526666 & 215058 & 113612 & 52.83 \\
\hline
\end{tabular}

Table 6. Inflow and outflow suspended sediment transport rate during the 2-day storm.

\begin{tabular}{lcccc}
\hline & \multicolumn{2}{c}{ Sediment yield of the watershed } & & \multicolumn{2}{c}{ Sediment flushing by the shaft spillway } \\
\cline { 2 - 4 } $\begin{array}{l}\text { Return } \\
\text { period }\end{array}$ & $\begin{array}{c}\text { Total soil } \\
\text { erosion }\left(\mathrm{m}^{3}\right)\end{array}$ & $\begin{array}{c}\text { Total sediment } \\
\text { yield }\left(\mathrm{m}^{3}\right)\end{array}$ & $\begin{array}{c}\text { Sediment } \\
\text { flushing }\left(\mathrm{m}^{3}\right)\end{array}$ & $\begin{array}{c}\text { Sediment flushing } \\
\text { efficiency }(\%)\end{array}$ \\
\hline $2 \mathrm{yr}$ & 443955 & 129199 & 75556 & 58.48 \\
$5 \mathrm{yr}$ & 557444 & 180498 & 104519 & 57.91 \\
$10 \mathrm{yr}$ & 627812 & 214128 & 120797 & 56.41 \\
$25 \mathrm{yr}$ & 701289 & 245998 & 137663 & 55.96 \\
$50 \mathrm{yr}$ & 793946 & 284515 & 156285 & 54.93 \\
$100 \mathrm{yr}$ & 862089 & 318857 & 174357 & 54.68 \\
$200 \mathrm{yr}$ & 918677 & 352599 & 182178 & 51.67 \\
\hline
\end{tabular}


and 14th hr, respectively. The waterstage in the reservoir began to drop when the level of inflow discharge was lower than that of the shaft spillway pipe release discharge. Consequently, the water stage in the reservoir reached its peak after the 18th $\mathrm{hr}$. However, the water stage in the reservoir for the two storms and various return periods exhibited some differences. The maximum discharge release of the shaft spillway pipe $(85 \mathrm{~cm})$ occurred at the highest water stage. Because the peak of the suspended sediment occurred earlier than that of the flow, the maximum flushing of sediment occurred just before reaching the highest water stage and the suspended sediment transport rate was approximately $3.65 \mathrm{~m}^{3} / \mathrm{s}$.

Empty flushing can increase detention space and decrease sediment siltation during the wet period. Tables 5 and 6 show the efficiency of empty flushing during the 1- and 2-day storms for the different return periods applied. For the 1-day storm, the lowest and highest efficiencies were $52.83 \%$ (200yr return period) and $55.07 \%$ (2-yr return period), respectively, with an average efficiency of $54.32 \%$. For the 2-day storm, the lowest and highest efficiencies were $51.67 \%$ (200-yr return period) and $58.48 \%$ (2-yr return period), respectively, with an average efficiency of $55.72 \%$. The simulation results were approximately $65.34 \%$, which agrees with the efficiency obtained from the hydraulic model test conducted in the laboratory (Water Resources Planning Institute 2003).

\section{Conclusions}

In this study, numerical simulations were conducted using a PSED model to determine the discharge hydrograph, hydrograph for sediment concentration into a reservoir, release discharge, and sediment flushing of a shaft spillway pipe. The model was further used to calculate the sediment yield of each subwatershed, sediment flushing amount, and shaft spillway pipe efficiency in flushing out sediment. Based on the simulation results for Typhoon Morakot and 1- and 2-day storm events, the following conclusions are drawn: The PSED model successfully investigated the flow discharge and concentration hydrograph of suspended sediment into the reservoir, sediment yield in the watershed, and the sediment flushing efficiency of empty storage. The results for Typhoon Morakot revealed that the peak flow figures of the observed results and simulated results were consistent. The simulation results for sediment yield from the Joushui and Wanglai Rivers watersheds were on average 70 and $30 \%$, respectively, which were consistent with those obtained by the Water Resources Agency report (72 and $28 \%$, respectively). These results indicate the applicability of the proposed model in simulating flow discharge into a reservoir and sediment yield in a watershed. The results further indicated that the efficiency of empty flushing is as high as 55\% when using the shaft spillway pipe for empty flushing.

\section{Acknowledgements}

The observed and hydraulic model test data for this study were provided by the Agongdian Reservoir Management Center, Southern Region Water Resources Office, Water Resources Agency, Ministry of Economic Affairs (MOEAWRA1000220). This study was supported by a grant from the Ministry of Science and Technology of Taiwan (MOST 103-2625-M-020-001). The author gratefully acknowledges this support.

\section{References}

Beasley D B, Huggins L F and Monke E J 1980 Answers: A model for watershed planning; Trans. ASAE 23, https:// doi.org/10.13031/2013.34692.

Brazier R E, Beven K J and Freer J et al. 2000 Equifinality and uncertainty in physically based soil erosion models: Application of the GLUE methodology to WEPP - the water erosion prediction project - for sites in the UK and USA; Earth Surf. Proc. Land 25(8) 825-845.

Castillo L G, Carrillo J M and Álvarez M A 2015 Complementary methods for determining the sedimentation and flushing in a reservoir; J. Hydraul. Eng. 141(11) 05015004 .

Chang F J, Lai J S and Kao L S 2003 Optimization of operation rule curves and flushing schedule in a reservoir; Hydrol. Process. 17(8) 1623-1640.

Chaudhry M A, Habib-ur-Rehman M and Akhtar M N et al. 2014 Modeling sediment deposition and sediment flushing through reservoirs using 1-d numerical model; Arabian J. Sci. Eng. 39(2) 647-658.

Chen C N, Tsai C H and Tsai C T 2006 Simulation of sediment yield from watershed by physiographic soil erosion-deposition model; J. Hydrol. 327(3-4) 293-303.

Chen C S, Chen Y L and Liu C L et al. 2007 Statistics of heavy rainfall occurrences in Taiwan; Wea. Forecasting 22(5) 981-1002.

Chen C N, Tsai C H and Tsai C T 2011 Simulation of runoff and suspended sediment transport rate in a basin with multiple watersheds; Water Resour. Manag. 25(3) 793816. 
Chow V, Maidment D R and Mays L W 1988 Applied hydrology; McGraw-Hill, New York.

Estakhri R 1999 Use of different infiltration equations in answers model and its effect on prediction of runoff and sediment; Dissertation, Shiraz University, Iran.

Hu S C, Lu J Y and Wu I Y et al. 1995 Interrill erosion rates of high clay soils in lien-hua-chi area; Bull. Taiwan Forest. Res. Inst. $1033-40$.

Itakura T and Kishi T 1980 Open channel flow with suspended sediments; ASCE 106 1325-1343.

Kondolf G M, Gao Y and Annandale G W et al. 2014 Sustainable sediment management in reservoirs and regulated rivers: Experiences from five continents; Earth's Future 2(5) 256-280.

Ma M M 1995 The rainfall characteristics and erosivity in central and northern areas of Taiwan; Dissertation, National Chung-Hsing University, Taiwan.

Morgan R P C, Quinton J N and Smith R E et al. 1998 The European soil erosion model (eurosem): A dynamic approach for predicting sediment transport from fields and small catchments; Earth Surf. Proc. Land 23(6) 527-544.

Mueller E N, Güntner A and Francke T et al. 2010 Modelling sediment export, retention and reservoir sedimentation in drylands with the WASA-SED model; Geosci. Model Dev. 3(1) 275-291.

Mutchler C K and Young R A 1975 Soil detachment by raindrops; Proceedings of Sediment-Yield Workshop.

Nearing M A, Foster G R and Lane L J et al. 1989 A process-based soil erosion model for USDA - water erosion prediction project technology; Trans. Am. Soc. Ag. Eng. 32 1587-1593.

Renard K G, Foster G R and Weesies G A et al. 1991 Rusle: Revised universal soil loss equation; J. Soil Water Consv. 46(1) 30-33.

Sharma P P, Gupta S C and Foster G R 1995 Raindropinduced soil detachment and sediment transport from interrill areas; Soil Sci. Soc. Am. J. 59(3) 727-734.

Singh R, Tiwari K N and Mal B C 2006 Hydrological studies for small watershed in India using the answers model; $J$. Hydrol. 318(1-4) 184-199.

Southern Water Resources Bureau 2010 Effect assessment of empty storage operation for sediment prevention observation program of Agongdian reservoir.
Sun H, Cornish P S and Daniell T M 2002 Contour-based digital elevation modeling of watershed erosion and sedimentation: Erosion and sedimentation estimation tool (eroset); Water Resour. Res. 38(11) 1-15.

Tena A, Vericat D and Batalla R J 2014 Suspended sediment dynamics during flushing flows in a large impounded river (the lower river Ebro); J. Soils Sed. 14(12) 2057-2069.

Tsai C H and Tsai C T 2000 Velocity and concentration distributions of sediment-laden open channel flow; J. Am. Water Resour. Assoc. 36(5) 1075-1086.

Tsai C H 2000 Numerical simulation of flow and bed evolution in alluvial river with levees; Dissertation, National Cheng-Kung University, Taiwan.

Tsai C T and Tsai C H 1997 A study on the applicability of discharge formulas for trapezoidal broad-crested weirs; J. Taiwan Water Conserv. 45(2) 2945.

Vanoni V 1975 Sedimentation engineering; American Society of Civil Engineers, New York, USA.

Water Resources Agency 2013 The climate change knowledge base on water and the environment.

Water Resources Planning Institute 2003 Hydraulic model studies on the functions and operations of silting prevention in A-kung-tien reservior.

Williams J R 1975 Sediment routing for agricultural watersheds; J. Am. Water Resour. Assoc. 11(5) 965974.

Wischmeier W H and Smith D D 1978 Predicting rainfall erosion losses: A guide to conservation planning; Science and Education Administration, U.S. Department of Agriculture, Purdue University, Agricultural Experiment Station, USA.

Wu C H, Chen C N and Tsai C H et al. 2012 Estimating sediment deposition volume in a reservoir using the physiographic soil erosion-deposition model; Int. J. Sedim. Res. 27(3) 362-377.

Yang C J 2000 Study on construction of a physiographic inundation forecasting system, Taiwan; Dissertation, National Cheng-Kung University, Taiwan.

Ziegler A D, Giambelluca T W and Sutherland R A 2001 Erosion prediction on unpaved mountain roads in northern Thailand: Validation of dynamic erodibility modelling using KINEROS2; Hydrol. Process. 15(3) $337-358$. 